\title{
A Review of Energy Storage Participation for Ancillary Services in a Microgrid Environment
}

\author{
G V Brahmendra Kumar (1) and K Palanisamy * \\ School of Electrical Engineering, Vellore Institute of Technology, Vellore 632014, India; \\ brahmendrakumar.g@gmail.com \\ * Correspondence: kpalanisamy@vit.ac.in
}

Received: 14 October 2020; Accepted: 14 December 2020; Published: 16 December 2020

check for updates

\begin{abstract}
This paper reviews the energy storage participation for ancillary services in a microgrid (MG) system. The MG is used as a basic empowering solution to combine renewable generators and storage systems distributed to assist several demands proficiently. However, because of unforeseen and sporadic features of renewable energy, innovative tasks rise for the consistent process of MGs. Power management in MGs that contain renewable energy sources (RES) can be improved by energy storage. The energy storage systems (ESSs) have several merits, such as supply and demand balancing, smoothing of RES power generation, enhancing power quality and reliability, and facilitating the ancillary services like voltage and frequency regulation in MG operation. The integration of ESS technology has become a solution to the challenges the power distribution networks face in achieving improved performance. By simplifying a smooth and robust energy balance within the MG, storage devices match energy generation to consumption. MG, and its multidisciplinary portrait of current MG drivers, tasks, real-world applications, and upcoming views are elucidated in this paper.
\end{abstract}

Keywords: microgrid; ancillary services; renewable energy sources; energy storage; power management

\section{Introduction}

As a result of improper regulation followed in the electric power industry and the continuing problems in the environment along with increasing energy consumption have led to an increase in installed capacity of distributed generation (DG) sources and energy storage systems (ESSs). These sources include various technologies in combined heat and power operation or purely for electricity production like microturbines, diesel engines, and fuel cells as well as photovoltaic (PV), hydro turbine, small wind turbines, etc. To balance the load and power of renewable sources, the stored energy is controlled, over time domain, lowering the full charge of energy at this level of mutual coupling [1]. Presently, the smart grid is the leading idea in the electric power industry. The key objective of developing a smart grid is to provide consistent, high-quality electrical power to digital societies in environmentally friendly and sustainable ways. The advanced structures that can simplify the links of many AC and DC generation systems, energy storage operations, and several AC and DC loads with the optimal asset utilization and operational efficiency are the most significant features of the smart grid. To achieve these objectives, power electronic technology plays a substantial role in interfacing various sources and loads to a smart grid [2].

Recently, microgrid (MG) technology has received significant attention from utilities around the world as a key approach to cost-saving asset replacement and strengthening of networks [3]. Electrical and energy engineers are now faced with a new scenario in which the grid must be integrated with small, distributed power generators and distributed storage (DS) devices. The new power grid, also known as the smart grid, would deliver electricity from producers to customers using digital 
technologies to monitor household appliances to save energy, reduce costs, and increase efficiency and transparency. In this context, the energy system must be more accessible, smart, and distributed. Without the use of DSs to deal with energy balances, there is no point in using DG. MG networks, also referred to as mini-grids, are becoming a key concept for the integration of DG and DS systems. The model is designed to cope with the penetration of RESs (Renewable Energy Sources) that can be practical if the end user is able to produce, store, monitor, and manage part of the electricity consumed. The end user is not just a consumer, but part of the grid with this paradigm change [4]. Using current technical progress, it is stress free and probable to have battery energy storage systems (BESSs) and loads and MG systems with the aggregation of localized energy sources [5]. MG technology has progressed over the years and is becoming more and more advanced. In addition to communication technology, electrical energy distribution and generation have been reformed with modern progression. Through an improved aggregation of RESs, the MG is composed to turn into a fundamental feature of new power systems. This innovative era technology is to assist service providers and consumers to yield absolute control over the cost of energy (COE), system reliability, and energy sustainability. MG technology is making rapid progress toward excellence with a substantial contribution from all stakeholders.

Various MG definitions [6] and their efficient categorization methods [7] can be seen in the literature. The MG Exchange Group from the U.S. Department of Energy and the Ad Hoc Group of research and development experts define the MG as follows: "A group of interconnected loads and DERs (Distributed Energy Resources) acting as a single controller to the grid within specified electrical limits. The MG can be connected and disconnected from the network so that it can operate in both grid-connected and island mode [8]".

A typical MG system is presented in Figure 1. This definition contains three requirements: (1) The part of the distribution system comprising a MG can be identified as different from the rest of the system; (2) resources associated to the MG are controlled by each other rather than by remote resources; and (3) whether it is connected to or not the larger grid, the MG can work [9].

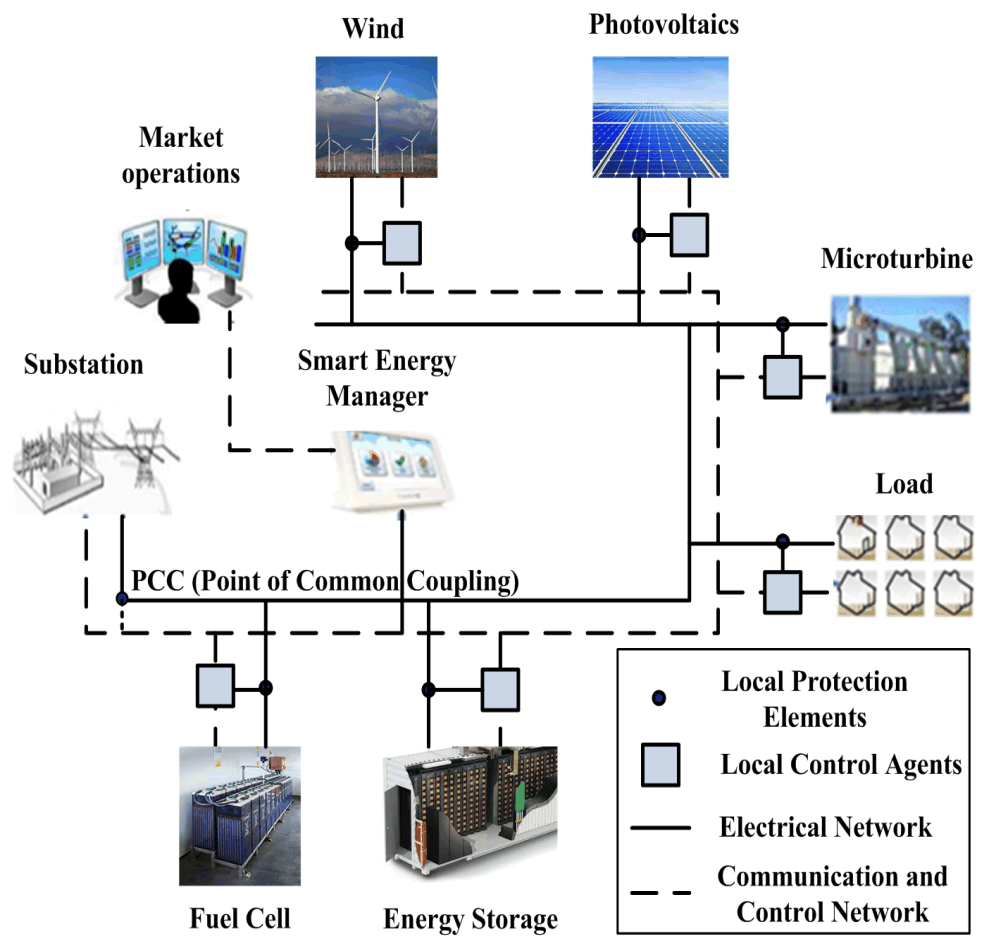

Figure 1. A typical system of microgrid (MG). 
MGs are more effective in owning and managing local problem areas and can also be used as a possible tool to achieve a "self-healing" smart grid for the future [10]. Societies can develop grid architecture models as smart supergrids or virtual power stations that do not have a local generation balance, load balancing, or isolating segments of the grid, which are more compelling designs.

Smart supergrids can detect, isolate, and restore capabilities to reduce congestion, routing energy around failures, and reduce recovery time from failures. Software and analytics can be used to manage a wide range of DERs of virtual power plants, although networked MGs can also serve as virtual power plants [11]. It is important that MGs become the dominant strategy for utilizing large amounts of intermittent renewable energy compared to alternative smart grid paradigms and that the benefits in terms of cost are sufficient.

One focus area is the voltage control market in MG distribution networks [12]. Some scientists suggest that in the future each MG will serve as a virtual power station (i.e., single aggregated DER) and each MG bids energy and ancillary services to the external power system based on the aggregation of offers from DERs within the MG. They design a day-ahead market for reactive power for the power flow from large generators to customers over a radial transmission and distribution network and provide a mechanism for optimal market settlement. This is a very similar vision as the roadmap in New York that proposes opening up the wholesale electricity market to DER aggregators [13].

Regarding the distribution grid's ancillary services, numerous studies have been carried out on MGs and grid stability relationships. MG with ESSs can perform additional tasks such as maintaining the local voltage at a given level, providing a backup system for critical local loads, etc. [14]. In [15], the optimum management of DER and energy storage can benefit the grid power balance. Recent research has proposed a state-of-the-art technology called transactive energy to operational resource planning to minimize energy costs and improve the delivery system stability through demand or price-tracking mechanisms [16]. The use of ESS in distribution networks is a good option to mitigate power system problems from the generation and transmission networks' operation to the small-scale distribution network and microgrid applications [17]. ESSs' facilities are numerous and are expected to progress in the future.

Microgrids are relatively small, controllable power systems consisting of one or more units of generation linked to near users, which can be operated with or without the local bulk transmission system. They can also use energy storage such as batteries in electric vehicles to balance microgrid output. Microgrids can contribute to deploying energy from zero emissions, minimizing energy loss through transmission lines, controlling power supply, and increasing grid resilience to extreme conditions [18].

Innovative business models like power purchase or energy-sale contracts and the development of properly owned operations play a major role in MG scalability. Power purchase agreements (PPAs) are set to play a bigger role in the MG market when MG design and procurement is simplified [9]. The PPA is currently a very successful business model in the U.S. residential and commercial solar PVs market because they can collect tax and other related incentives while avoiding the large initial cost of capital for a plant that hosts the system.

The PPA infrastructure is owned and rented by a third party to provide electrical and related services to end users. In the MGs' sector, improved reliability, sustainability, and economic benefits such as energy cost savings can be placed on the market. In combined projects, such as cooling, heating, and power, thermal energy can also be combined with electricity in the PPA. Operations and maintenance can be reasonably expected to be part of PPA, since the revenues from the PPA depend on the operating systems to their full potential.

In the late 1990s, researchers and engineers in the U.S. and Europe began looking for decentralized solutions that could manage the integration of tens or thousands of DERs to enhance reliability and resilience against natural disasters, physical and cyber assaults, and power failures [19]. The solution to this is a network architecture that can manage power generation and demand in subdivisions of the grid, isolated from an automated large grid to provide critical services even when the grid fails. 
MG development in the U.S. was driven mainly by their ability to increase the resilience of critical facilities such as transportation, communication, and emergency response infrastructure, which can quickly bounce back from complication and reliability (at times acceptable levels of services) [20]. One of the main regions of the U.S., the Northeast, has suffered billions of dollars lost in aging infrastructure and often severe weather events in recent years. Thus, states are exploring the possibilities of expanding MG services in critical infrastructure to serve entire communities.

New York State's "New York Prize", a competition of \$40 million to help communities deal with issues ranging from feasibility studies to implementation, is the most notable example of state support for community MGs [21]. In the U.S., states seek MGs as an alternative to retiring power generation and to reduce congestion points in the transmission and distribution system. Climate scientists have concluded that human societies should reduce the share of electricity from the burning of fossil fuels from $70 \%$ (in 2010) to below $20 \%$ by 2050 to prevent global average temperature rise above preindustrial levels, now accepted as the threshold for "safe" and "dangerous" climate change [22].

To address these gaps, many energy sources are decentralized, intermittent, and uninterrupted, and it is challenging for them to integrate the existing grid designed to supply one-way power flow from centralized power stations to customer loads. Deploying intermittent renewable energy in MGs with flexible loads and storage technology enables local supply and demand balance, making it possible for widespread renewable distribution. Installation for distribution service providers has potential to change the way a small source or electricity user benefits the main grid rather than tracking and coordinating the net loading profile of thousands or millions of individual DERs [23]. A wide range of criteria, including carbon emissions, investment costs, electricity costs, and others, are currently being investigated for the design of MGs using sophisticated analytically developed approaches.

A wide variety of DERs can be used in MGs in various multidisciplinary studies, reviewed in [19]. MGs appear to be technology agnostic, and design choices depend on specific project requirements and economic considerations. The inclusion of ESSs prevents MG deficiencies. Since most MG sources lack the inertia of large synchronous generators (SGs), a buffer is needed to minimize generation and demand imbalances. The load diversity of larger geographical areas is also lacking in MG systems, which means they have to deal with much greater relative variability. There are a number of currently emerging ESS technologies that could play a possible role in MGs [24]. The ability of ESS facilities to provide ancillary services, such as voltage control support, spinning reserves, load following, and peak shaving among others, has been briefly discussed in the following sections.

In this paper, Section 2 describes the generation and storage options. Ancillary services and their classifications and available ancillary services across the globe are explained in Section 3. The drivers of MG development and deployment and applications of MG are studied and reviewed in Section 4, and Section 5 is the conclusion.

\section{Generation and Storage Options}

To improve the reliability and power quality of the grid, storage systems along with RES are used. Storage features support the needs of a grid network [25] and:

- Ensure the grid energy balance,

- $\quad$ Provide fault ride-through (FRT) capability under dynamic variations, and

- In MGs, assist the smooth transition from islanded mode to normal modes.

Some examples of options available for today's generation and storage, including their advantages and disadvantages, are listed in Table 1 [26-32] below. Fuel cells (FCs), batteries, flywheels (FES), and supercapacitors (SCs) are the most commonly used energy storage devices [25]. Among these, flywheel is not currently the most attractive solution because of its self-discharge problems, the need for vacuum chambers, and the maintenance of superconducting bearings [33]. 
Table 1. Overview concerning the generation and storage options in MGs (Microgrid).

\begin{tabular}{|c|c|c|c|c|}
\hline Reference & Category & Storage Options Employed & Benefits & Drawbacks \\
\hline [26] & Generation & $\begin{array}{l}\text { Diesel and Spark Ignition (SI) reciprocating } \\
\text { internal combustion engines }\end{array}$ & $\begin{array}{l}\text { Easily dispatchable in nature. } \\
\text { Faster start-up and load-following. } \\
\text { Used for combined heat and power (CHP). }\end{array}$ & $\begin{array}{l}\text { Particulate and Nitrogen oxide emissions. } \\
\text { Likely emission of greenhouse gases. } \\
\text { Generation of noise. }\end{array}$ \\
\hline [27] & & Microturbines & $\begin{array}{l}\text { Dispatchable. } \\
\text { Multiple fuel options. } \\
\text { A lower degree of emissions. } \\
\text { Simplicity under mechanical aspects. } \\
\text { CHP-capable. }\end{array}$ & $\begin{array}{l}\text { The maintenance cost is high. } \\
\text { Cooling is necessary, even if heat retrieved is not reusable. }\end{array}$ \\
\hline$[28,29]$ & & $\begin{array}{l}\text { FCs (including molten-carbonate, solid oxide, } \\
\text { alkaline, and phosphoric acid, } \\
\text { low-temperature PEM) }\end{array}$ & $\begin{array}{c}\text { Dispatchable. } \\
\text { Zero on-site pollution. } \\
\text { CHP-capable. } \\
\text { Greater efficiency available versus micro turbines. }\end{array}$ & $\begin{array}{l}\text { Comparatively, they are expensive. } \\
\text { Limitations of mechanical strength and fatigue. } \\
\text { It is less mature than chemical batteries. } \\
\text { The current cost is too high to make them commercially } \\
\text { competitive. }\end{array}$ \\
\hline$[27,29]$ & & $\begin{array}{l}\text { Renewable generation (solar PV cells, small } \\
\text { wind turbines, and mini-hydro) }\end{array}$ & $\begin{array}{l}\text { Cost effective in terms of fuel generation. } \\
\text { Zero emissions. } \\
\text { Maintenance requirements are lower than traditional fuel sources. }\end{array}$ & $\begin{array}{l}\text { The upfront cost is higher. } \\
\text { Geographical constraints. } \\
\text { Need a capable load-following generator. } \\
\text { Lack the much-needed efficiency. } \\
\text { Variable and regarded as uncontrollable in nature. }\end{array}$ \\
\hline$[30,31]$ & Storage & $\begin{array}{l}\text { Batteries (including lead-acid, sodium-sulfur, } \\
\text { lithium-ion, and nickel-cadmium) }\end{array}$ & $\begin{array}{c}\text { A long history of } \\
\text { R \& D. } \\
\text { Round-trip efficiency is between } 75-90 \% \text {. } \\
\text { High performance and lower maintenance. }\end{array}$ & $\begin{array}{l}\text { A limited number of charge-discharge cycles. } \\
\text { Complications in terms of waste discharge. } \\
\text { Battery degradation costs. }\end{array}$ \\
\hline [30] & & $\begin{array}{c}\text { Flow batteries (FBs) referred to as regenerative } \\
\text { FCs (Comprised Zn-Br, polysulphide bromide, } \\
\text { vanadium redox) }\end{array}$ & $\begin{array}{l}\text { Decouple power and energy storage. } \\
\text { Round-trip efficiency is up to } 75 \% \text {. } \\
\text { Ability to support continuous operation under maximum load. } \\
\text { Total discharge is possible without any risk of damage. }\end{array}$ & $\begin{array}{l}\text { Relatively under the early stage in terms of deployment. } \\
\text { Lower power density. } \\
\text { More complex. } \\
\text { Components and chemicals used in the flow batteries are } \\
\text { still comparably expensive. }\end{array}$ \\
\hline [32] & & Hydrogen from hydrolysis & $\begin{array}{l}\text { Clean. } \\
\text { Can store for a long period. }\end{array}$ & $\begin{array}{l}\text { Relatively low end-to-end efficiency. } \\
\text { Challenges concerned with hydrogen storage. } \\
\text { Components' cost is high. }\end{array}$ \\
\hline [32] & & Kinetic energy storage (flywheels) & $\begin{array}{c}\text { Fast response. } \\
\text { Overall costs are low. } \\
\text { High in terms of charge-discharge cycles. } \\
\text { Round-trip efficiency is } 85 \% .\end{array}$ & $\begin{array}{l}\text { Discharge time is limited. } \\
\text { High standing losses. } \\
\text { Maintenance is required. }\end{array}$ \\
\hline
\end{tabular}


Table 1. Cont.

\begin{tabular}{|c|c|c|c|c|}
\hline Reference & Category & Storage Options Employed & Benefits & Drawbacks \\
\hline [34] & & Pumped Hydro Energy Storage (PHES) & $\begin{array}{c}\text { Free from environmental impacts. } \\
\text { Sources are plentiful, clear, and reliable. } \\
\text { No reserve shortfalls. } \\
\text { Comparatively economical. } \\
\text { Very long lifetime. } \\
\text { Round-trip efficiency is } 70-80 \% \text { based on the distance and } \\
\text { gradient between upper and lower reservoirs. }\end{array}$ & $\begin{array}{l}\text { Expensive to build. } \\
\text { Geographical constraints. } \\
\text { Construction period is longer. } \\
\text { Maintenance is required. } \\
\text { Uncertainty of ease of use of water; if the water is not } \\
\text { available, difficulty in producing the electricity. } \\
\text { Overflow impacts. }\end{array}$ \\
\hline [34] & & Compressed Air Energy Storage (CAES) & $\begin{array}{l}\text { Energy storage capacity is high } \\
\text { Cost } / \mathrm{kWh} \text { is low. } \\
\text { Long lifetime. } \\
\text { The need for power electronic converters is less. }\end{array}$ & $\begin{array}{l}\text { The necessity for fuel and underground cavities. } \\
\text { Investment cost is high. } \\
\text { Geographical constraints. } \\
\text { Efficiency is low. }\end{array}$ \\
\hline [34] & & SC & $\begin{array}{c}\text { High power and energy density compared to normal capacitors. } \\
\text { Highest round-trip efficiency up to } 96 \% \text {. } \\
\text { Speed charging ability and faster response time. } \\
\text { Environmentally friendly. }\end{array}$ & $\begin{array}{l}\text { The self-discharge rate is high and low energy density } \\
\text { compared to batteries. } \\
\text { It cannot be utilized in AC and high-level frequency circuits. }\end{array}$ \\
\hline [34] & & $\begin{array}{l}\text { Superconducting Magnetic Energy } \\
\text { Storage (SMES) }\end{array}$ & $\begin{array}{l}\text { Power capability is high. } \\
95 \% \text { round-trip efficiency. } \\
\text { No environmental impacts. } \\
\text { Faster response time. } \\
\text { Capable of part and deep discharges. }\end{array}$ & $\begin{array}{l}\text { Lower energy density. } \\
\text { Raw materials, operation, and manufacturing processes } \\
\text { are expensive. }\end{array}$ \\
\hline
\end{tabular}


The FC changes the chemical energy in hydrogen to electrical energy. Modern heat engines use intermediate mechanical energy conversion to generate electricity from chemical energy, resulting in lower efficiency compared to FCs. FCs combine engines and batteries to their best advantage. As long as fuel is available, they act as engines and there is no intermediate mechanical energy conversion, and the FC characteristics are similar to batteries under load conditions. In relation to other challenging technologies, FCs have an extended life span of 20 years. However, FC gets great prices, especially for electrolyzers and efficiency issues. The main drawback of FC is that it is not subject to fast load variations, which lead to fuel starvation in the cells, which is short of cell lifetime. This describes the energy storage mechanism in the form of hydrogen gas in FC [35]. Compared to SCs' high discharge currents and low power densities, batteries have good energy densities as storage elements but suffer from longer recharging time. The SC storage element, which has a higher power density, has low energy density [34].

\section{Services in Electric Power Industry}

Services involved in the electric power industry are as follows.

\subsection{System Services}

System services are all services given by some system function (for instance, a system operator or a grid/network operator) to the users of the system. Power transmission, generation, and energy supply are basic system services [36].

\subsection{Ancillary Services}

Some users, such as generators, use the system frequency or voltage at a time when they are connected to the system to support these systems. These services provided by consumers are referred to as ancillary services because they are associated with energy production or consumption. These services are vital to maintaining the stability and reliability of the operation of the electrical system. From the traditional point of view, ancillary services are provided by large power plants and equipment with adequate capacity and capability. However, with improvements in MG technology, researchers and industries have been re-examining the role of MGs in promoting services. MGs provide ancillary services as long as they meet the technical requirements, and it is believed that ancillary service provision is one of the most important benefits of providing MGs.

From the perspective of aggregation mechanisms along with control capabilities on distributed power units, the technical feasibility of providing frequency and voltage control services through MG has been examined [30]. DGs can support voltage and frequency stability of power systems with appropriate coordination. Most DERs are interconnected by power electronic devices, and researchers have found that power electronic interfaces can provide some support for DER integration, particularly reactive power-related services. Reference [27] demonstrated the ability to use DGs with power electronic interfaces to provide ancillary services such as voltage control.

The possibility of supporting voltage through wind turbine generators has been investigated [26]. In [37], two models were developed based on the MG central controller concept, which allows the MG to participate in both energy and ancillary services' markets. The capacity underlying single MG might be too small in provisioning ancillary services and investigated the underlying technical problem of frequency control by multiple MGs and proposed a centralized control approach and decentralized approach for aggregation. The generating capacity of DGs allows MGs to benefit from both power generation and active power reserve. For profit maximization, optimizing the bidding strategy for both the energy and ancillary service markets to simultaneously participate has been identified, and this is a problem that has attracted the attention of researchers [29]. 
Different types of DGs may have different behaviors in providing ancillary services due to their distinct fundamental characteristics. Therefore, the profitability for those DGs should be investigated separately. The study involving [27-29] gives detailed modeling of how profit can be achieved by providing active power reserve and comparing the profitability of active power storage from different energy sources.

The author argues that renewable sources are not profitable for active power reserve, as they have a high opportunity cost caused by their low operating cost (e.g., wind energy generators and solar energy generators have zero fuel cost due to the free wind and sunshine, which makes their operating cost lower than fuel-based generators). In addition to DGs, load and ESS are also good candidates for frequency control services. Loads that participate in frequency control service must be dispatched and interruptible; also, the loads prefer to be used as a contingency reserve (e.g., a spinning reserve), which is often not used [37]. Some research has been done to minimize the manipulation of the load while providing frequency control service in [38].

Loads have several advantages over the generators on providing ancillary services. Compared to generators, loads are usually smaller in size, so an aggregation of the small load is more reliable than a single, large generator. Secondly, loads can react faster since curtailment of the load is usually faster than ramping up a power plant. Thus, they are well matched to the fast, short, and infrequent events. Finally, using loads can prevent additional investment in generators and transmission lines. In order to be good candidates for spinning reserve, loads must have the following characteristics: capability of storing energy, control capability, fast communication, adequate aggregation size, low cost, quick response, and restoration [32,39]. The above features are also noted in [40], in which the authors demonstrated that the thermostatically controlled loads that can be quickly disconnected are ideal for providing a frequency control service because they can be energy efficient and cost effective. In [41,42], the capability potential of thermostatically controlled load for ancillary services is further illustrated. The efficiency of the load is taken into account not only from a technical perspective but also from market and policy barriers. In [43], an optimization approach to increase the profits of the load in the ancillary service market was proposed.

System and ancillary services are interdependent and complex because both system and ancillary services are required simultaneously by the same supplier [44]. Applications of ESS provide a variety of services. In this, the terms and conditions of the specified 'service' and 'application' are reviewed and interchanged. The term 'service' refers to the electrical operation accomplished by ESS with its power conversion system, and the term 'application' defines connection and the location of the grid and the ESS functionality concerning its infrastructure as well as its technical features. An overview of ESS pilot projects around the world for various application areas is presented in Table 2.

\subsection{Classification of Ancillary Services}

The system operator must ensure the required level of quality and safety to maintain the integrity and reliability of the system, take preventive measures for contingency control and perform many other duties. The operator should be able to adjust the frequency and voltage of the system within certain limits, maintain the reliability of the system, avoid overload on the transmission system and, if necessary, re-establish the system [46].

In order to maintain system reliability in view of events and contingencies, a suggested list in Table 3 for the system operator is presented. It has been concluded that all ancillary services are important and they meet the previous requirements. The detailed classification of ancillary services is presented in Figure 2. Ancillary services are fretted through the delivery of power, trade, and dispatch. They are usually characterized by the benefits they provide to market members [47]. The following Table 3 lists the different classifications of ancillary services in the literature from various sources. 
Table 2. Overview of ESS (Energy Storage System ) pilot projects across the world for various application areas [45].

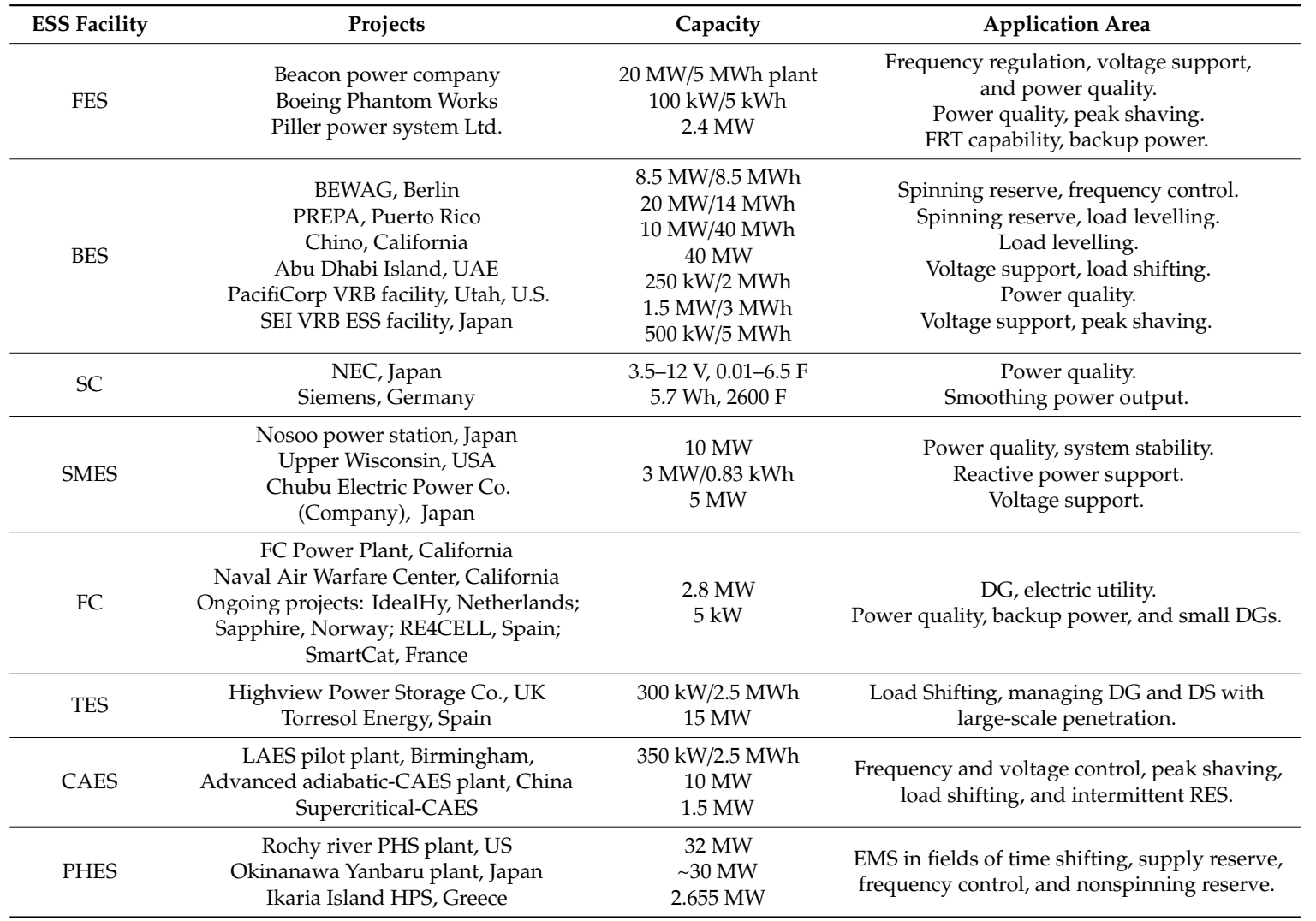

Table 3. Key characterizations of ancillary services.

\begin{tabular}{ccc}
\hline References & Source & Contribution \\
\hline & & Frequency and voltage control services \\
& Black start \\
& & Scheduling and dispatch \\
& & Financial trade enforcement \\
& Transmission security \\
& & System security \\
& CIGRE/FERC/Power System & Load-Following \\
& Economics and other Authors & Loss Compensation \\
& & Energy imbalance \\
& Operating reserve \\
& Reactive power control \\
& Real-power balancing \\
\hline
\end{tabular}

The different lists of ancillary services mentioned above are mainly about how they divide and integrate various types of services. Broadly, each of these services can be classified as one of the following three main categories:

- Frequency control services,

- Network control services, or

- $\quad$ System restart services. 


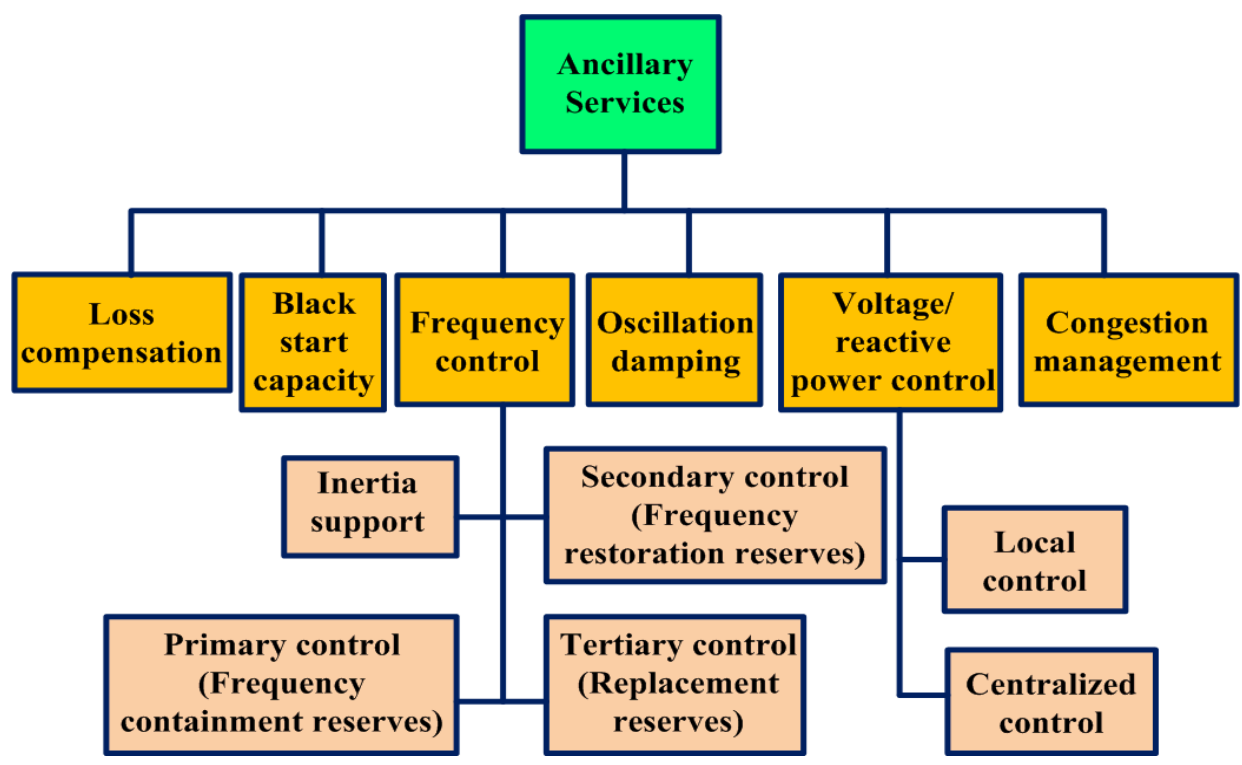

Figure 2. Classification of ancillary services.

\subsubsection{Frequency Control Services}

Frequency is the measure of the active power produced and consumed, both of which must be balanced to allow the operation of an AC system. The basic functionality of the power system is represented in Figure 3.

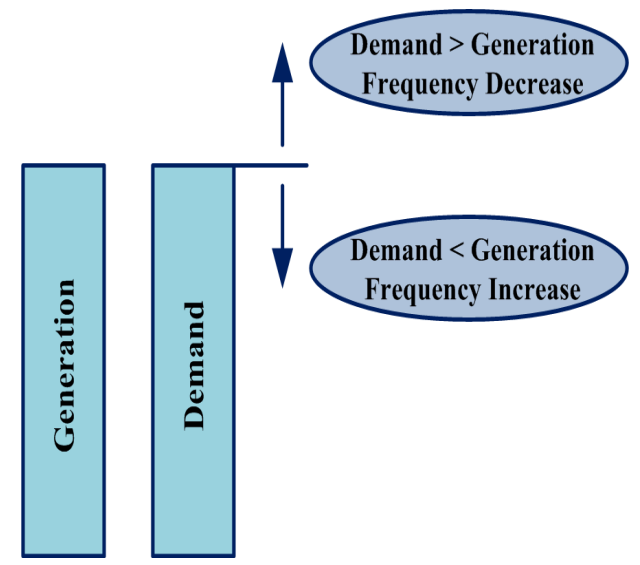

Figure 3. The basic behavior of the power system network.

Therefore, the frequency is considered as a pointer to standardize the active power output to balance them out [51]. For system security, frequency control is required. The variation in frequency is usually within a certain acceptable range for the secure operation of the electrical system and the safe and reliable operation of connected devices. Since power consumption is different, it is essential to control the active power output accordingly. The following Figure 4 shows the process at various frequency levels [52].

Technical factors underly frequency control services. Deployment times are important, specific characteristics of frequency-related ancillary services. The 'Deployment Start' is the entire period between the request of a particular network operator and the response of the service provider [53]. 'Deployment End' means the maximum time the service can be delivered from demand. 


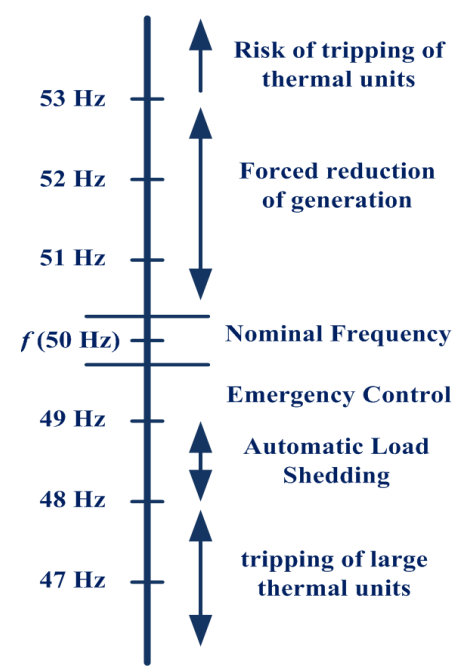

Figure 4. Different frequency levels of operation.

Levels of Frequency Control

To maintain the balance between generation and demand, the following levels of controllers are used [54], as shown in Figure 5:

(1) Primary,

(2) Secondary,

(3) Tertiary,

(4) Time control.

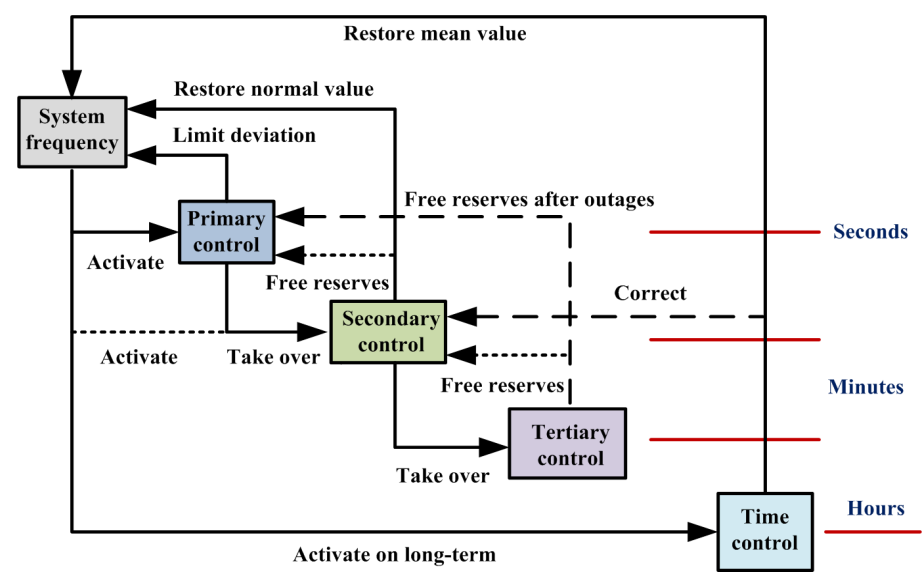

Figure 5. The function of various types of frequency reserve controls in the UCTE (Union for the Coordination of Transmission of Electricity) region [54].

All control levels are different with the change in response to time and the approach used to understand the basic operational perspective [55].

- Primary control is initiated within seconds as a collective action by all concerned parties or transmission system operators (TSOs).

- Secondary control replaces the primary control over minutes and is enforced by the responsible parties/TSOs.

- Tertiary control partly completes the secondary control and then replaces it with rescheduling generation and is enforced by responsible parties/TSOs. 
- Time control corrects the global synchronous time deviations as a joint action by all parties on a long-term basis.

\section{i. $\quad$ Frequency Control for Primary}

The primary control is the active power output of the generating unit to control the variation in frequency and control the use in controllable loads. It is specially designed to control the frequency during major generation and load interruptions. Therefore, it is essential for the stability of the power system. This control is automatically done by all the generators in the synchronous area equipped with the speed governor. The self-regulation effect of frequency-sensitive loads such as induction motors or the behavior of frequency-sensitive relays that connect or disconnect certain loads at specified frequency limits are also involved in this control [56].

Primary control source: To reduce unforeseen transits after a significant disturbance, primary frequency reserves should be uniformly distributed over the network. In the case of islanding, the uniform distribution also helps to maintain the stability of the system. Primary control and load monitoring are particularly suited for hydraulic turbines/stations. In these machines, the unit load can be easily adjusted and the units can be installed/completed without significant stress or loss of output. In some cases, further consideration of water release (irrigation, minimum flow, etc.) should be restricted to the load following. If there is no free board at canal-based hydro stations, no primary control or load following is possible [57].

Gas turbine stations are suitable for load following because they are controlled in/out but do not work for primary control, as they must be operated at a constant firing temperature (equal to efficiency and life) $[52,53]$. Increasing the fuel injection to increase the megawatts will cause the firing temperature to be higher than it can sustain continuously. Reducing the fuel injection to decrease the MW, thus reducing the firing temperature and changes in fast/frequent firing temperature, causes thermal over-stressing. By lowering the firing temperature, the efficiency is also reduced. For steam turbines, efficiency decreases slightly at partial load because the steam parameters can be held at rated levels and can also provide primary control and load monitoring. In a short period, the active power from the steam turbine can be improved by the action of the valves providing the primary response. For longer periods, it is important to adjust the primary input power such as the fuel flow [58]. When two systems are interconnected, High-voltage DC transmission can also be used as a primary controller, particularly in installed power systems where the frequency is closely controlled and enough spinning reserves are available.

\section{ii. Frequency Control for Secondary}

Secondary frequency control is a centralized automatic control that optimizes the generating units active power production to restore their target values after frequency mismatch and interchange with other systems. This process can be done by adjusting the generator set point or reference point or by starting and stopping of power plants. Secondary control should only be used for the generating units placed in the control area where an imbalance has occurred [44]. To reduce the area control error (ACE) is the goal of secondary frequency control. The primary frequency control must be adjusted to maintain the active power balance after an abrupt change in load capacity. This will result in a frequency change in the power plants due to a permanent drop of the primary frequency control. However, this can lead to the variation of power transfer between the control areas from the intended power transfer in the control system. Automatic secondary frequency control restores the scheduled power transfer.

Secondary frequency control is used to bring the ACE to zero using a proportional-integral (PI) controller and filters. Secondary frequency control in UCTE (Union for the Coordination of Transmission of Electricity) is also known as load frequency control (LFC) and is called automatic generation control (AGC) in North America. 


\section{iii. Frequency Control for Tertiary}

Tertiary frequency control applies to manual changes within the dispatching and responsibility of generating units. The control is used to recover primary and secondary frequency control reserves, manage transmission network congestion, and restore frequency or interchange their target value when this last function cannot be performed by the secondary control [44].

\section{iv. Time Control}

Time control makes the average frequency equal to the normal frequency of $50 \mathrm{~Hz}$. If the average frequency change reaches the above threshold point, the fixed frequency point in the entire synchronous zone is either set at $49.99 \mathrm{~Hz}$ or $50.01 \mathrm{~Hz}$ for complete, one-day periods [54]. The realization of these controlling frequency stages for a generating unit with the support of feedback control loops is presented in Figure 6.

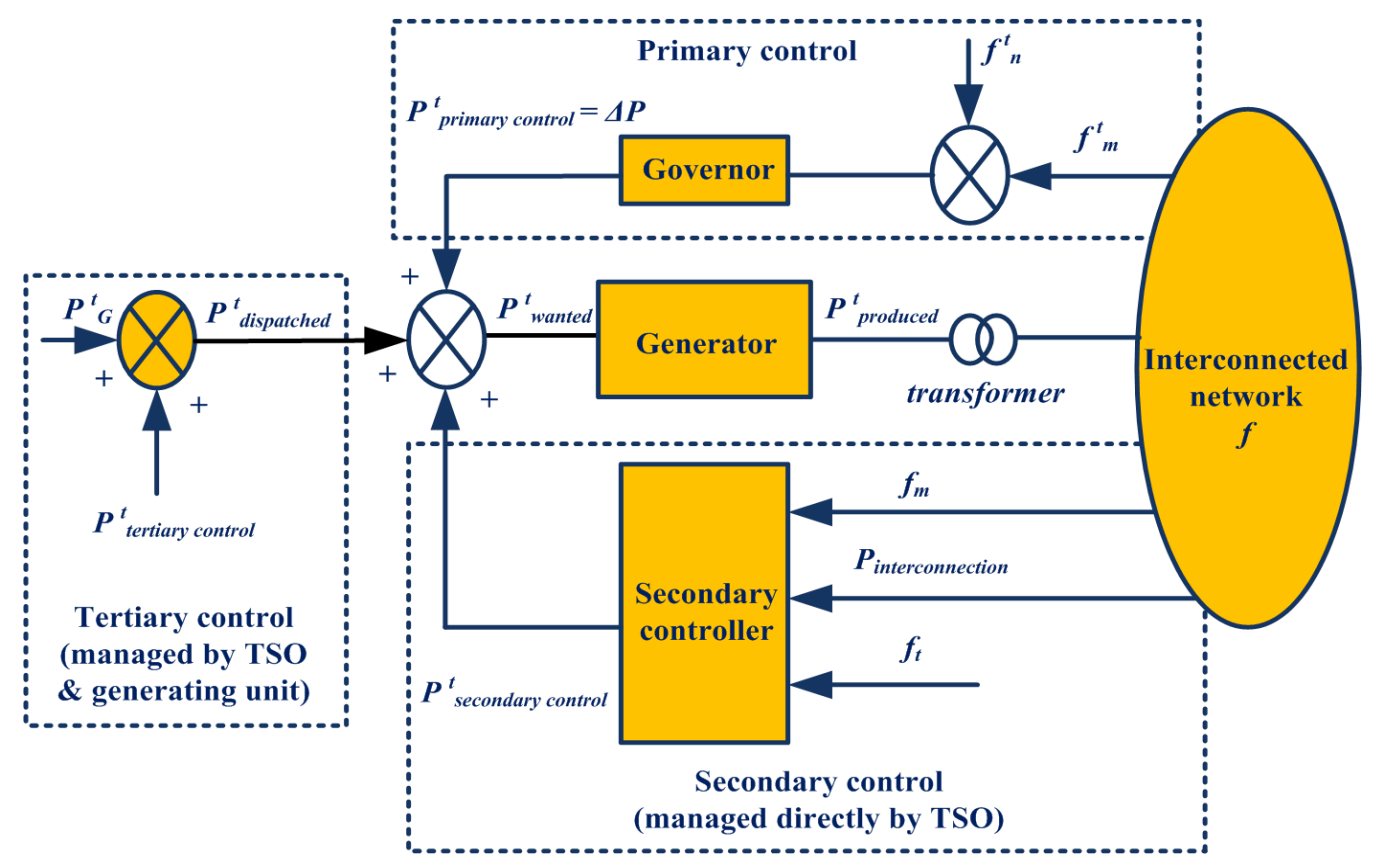

Figure 6. Three operational frequency regulations of a generator.

Frequency Reserves

Frequency reserves are necessary to maintain the integrity of the system in case of active power consumption and irregularities in production. These conditions may be caused by generation failures or variations in load. The required amount of reserves depends on the probability of multiple generation failures and variations in load. For example, if a system is loaded with more arc furnace, the reserve requirement of the system increases because the arc furnace load is very unpredictable. However, if a generator is subject to frequent interruptions, the required reserves will not change but the use of reserves will increase. The policy difference between UCTE and NERC (North American Electric Reliability Corporation) and their terminology are presented in Table 4.

The types of frequency controls listed above in the review have some reserves in order to address variations in frequency as a response to the generation capacity/load management [60]. Figure 7 shows the use of reserves for various types of a frequency control for a typical generating unit. Frequency reserves can be divided into the following broad groups: 


\section{i. $\quad$ Spinning Reserves/Reliability Reserves}

The spinning reserve is the additional generating power required to improve the power output of the generators already associated with the power system. Spinning reserves are necessary as demand may change and fast responses are required according to short-term standards. This category includes very quick operation units or controllable loads [59]. Such reserves are unable to continue for long durations at increased power consumption. Therefore, they will inevitably be supplemented by additional reserves. Coordinated internal combustion engines or hydro units can provide this.

\section{ii. Supplementary Reserves}

Their response time does not have to be as fast as spinning reserves, but they must be able to operate for longer duration at increased power output. For activation, they often require manual intervention. The reserve is also provided by the generation of hot standby units [59].

\section{iii. Backup Reserves}

These are reserves that can last for a considerable period of time (within hours) but should not come online for a certain amount of time (usually 30 min or more) [59].

Table 4. Policy differences between UCTE and NERC (North American Electric Reliability Corporation) [59].

\begin{tabular}{|c|c|c|}
\hline Reserves & UCTE & NERC \\
\hline Terminology & $\begin{array}{l}\text { Primary control reserve } \\
\text { Secondary control reserve } \\
\text { Tertiary control reserve }\end{array}$ & $\begin{array}{l}\text { Frequency responsive reserve } \\
\text { Regulating reserve } \\
\text { Spinning reserve } \\
\text { Non-spinning reserve } \\
\text { Non-spinning reserve } \\
\text { Supplemental reserve }\end{array}$ \\
\hline Regulating & $\begin{array}{l}\text { UCTE recommends a secondary reserve control } \\
\text { requirement based on the statistical equation and mainly } \\
\text { based on load variability. } \\
\text { However, both contingencies and normal variations are } \\
\text { subject to secondary reserves. Compliance measures are } \\
\text { not available. }\end{array}$ & $\begin{array}{l}\text { CPS enforcement provisions are imposed by the } \\
\text { NERC but do not have a regulation on the amount of } \\
\text { the current reserve regulating requirements. } \\
\text { The requirements of the CPS are based mainly on the } \\
\text { time of day and season. }\end{array}$ \\
\hline Following & $\begin{array}{l}\text { No UCTE requirements. } \\
\text { Used to minimize ACE for slower normal variations in a } \\
\text { control area. }\end{array}$ & NERC does not provide any standard or direction. \\
\hline $\begin{array}{l}\text { Replacement/ } \\
\text { Contingency }\end{array}$ & $\begin{array}{l}\text { The DCS criterion is identical. } \\
\text { Return ACE in } 15 \text { min to zero. } \\
\text { Sufficient of these reserves should be provided to } \\
\text { support the most significant contingency. }\end{array}$ & $\begin{array}{l}\text { DCS would return ACE to zero or its pre-disruption } \\
\text { point in } 15 \text { min, if negative. Sufficient contingency } \\
\text { reserves needed to recover the largest contingency. } \\
\text { For many regions, at least } 50 \text { percent of the spin is } \\
\text { required. }\end{array}$ \\
\hline Primary & $\begin{array}{l}\text { Complete response at } 200 \mathrm{mHz} \text {. } \\
\text { Characteristics of response based on UFLS relay setting } \\
\text { and safety margin of } 200 \mathrm{mHz} \\
\text { Peak insensitivity of } 20 \mathrm{mHz} \text {. }\end{array}$ & $\begin{array}{l}\text { Only a requirement for frequency bias as a part of } 1 \% \\
\text { peak ACE calculation. } \\
\text { The dead bands of governors usually settled at } 36 \\
\mathrm{mHz} \text { and dropped } \\
\text { by } 5 \% \text {. }\end{array}$ \\
\hline Ramping & No UCTE requirement for the ramping reserve. & $\begin{array}{l}\text { No constraints. } \\
\text { Used for rare severe events that do not take place } \\
\text { immediately. }\end{array}$ \\
\hline Secondary & $\begin{array}{l}\text { The UCTE policy recommends that the secondary } \\
\text { reserve be initiated within a maximum of } 30 \mathrm{~s} \text { after the } \\
\text { disturbance and returned to the initial ACE within a } \\
\text { maximum of } 15 \mathrm{~min} \text {. }\end{array}$ & $\begin{array}{l}\text { The Contingency reserve and the Ramping reserve } \\
\text { are used as a secondary reserve to restore the } \\
\text { frequency to its nominal value and to reduce the } \\
\text { ACE back to zero. }\end{array}$ \\
\hline Tertiary & $\begin{array}{l}\text { The need for tertiary control reserves is greater than the } \\
\text { largest contingency. } \\
\text { It is not necessary to replace reserves as long as possible. }\end{array}$ & $\begin{array}{l}\text { No quantifiable requirement, but the contingency } \\
\text { reserve has replaced within } 105 \text { min of contingency. }\end{array}$ \\
\hline
\end{tabular}

CPS, control performance standard; UFLS, under frequency load shedding; DCS, distribution control standard. 


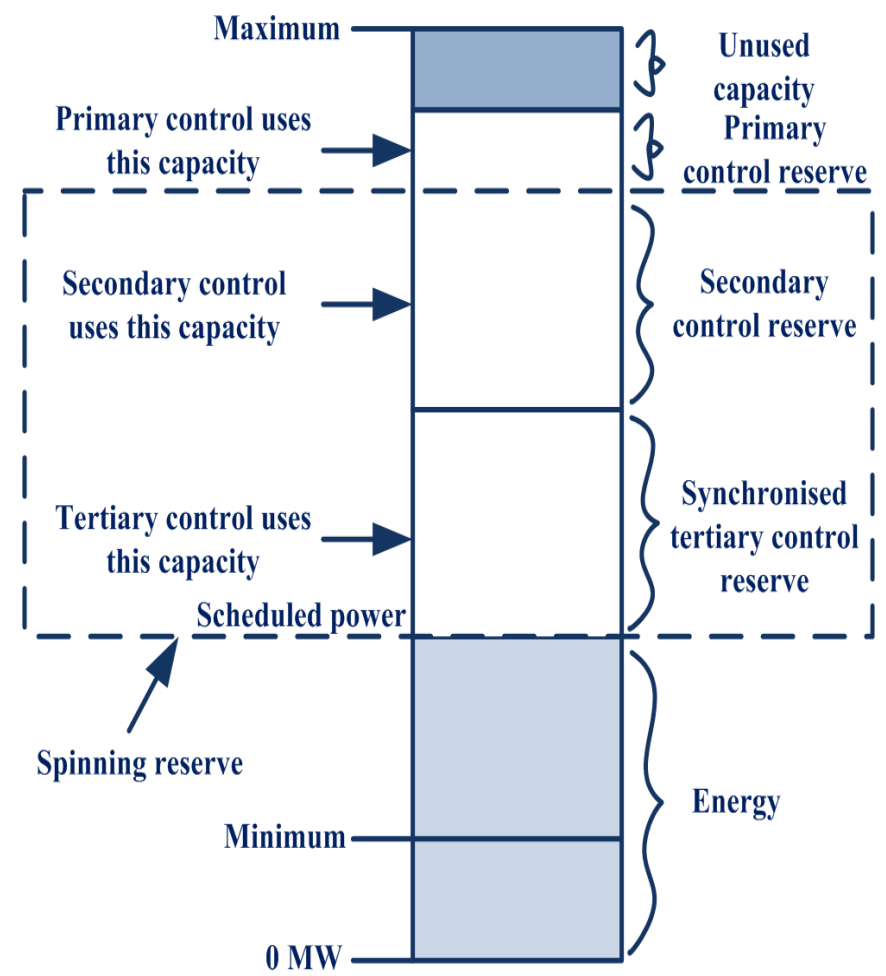

Figure 7. Control levels for a generating unit.

\subsubsection{Ancillary Services for Voltage Control}

The additional standard parameter for power quality is system voltage. The voltage is regulated by controlling the reactive power injection and the drawl within the power system. Network flows create voltage rises and drops as a result of interactions between flows and the transformer line inductance and capacitance.

\section{Requirements for Voltage Control}

The system voltage control is used to sustain the voltages at several nodes in the system, which requires precise bounds and the reactive power required in the system. Due to high inductance lines and transformers, the reactive power is not transmitted well through the grid, thereby supporting the reactive power as much as possible. Voltage control is necessary for the following reasons [61]:

- The equipment of voltage supply should be in its design bounds for safe process and excessive implementation.

- The system voltage varies then creates the changes in reactive power that widely affect the system losses.

- Voltages may also limit the system's transfer capability.

- Reactive power injection and absorption are also important for maintaining system stability, especially to avoid contingencies, which can lead to voltage collapse. Reactive power must have sufficient capacity to meet the required demands and the margin of reserve for possible outcomes. Local voltage regulation is a consumer service designed to meet consumer reactive power requirements and monitor each consumer's impact on network voltage and system failure. Therefore, power factor problems at a customer site do not affect power quality elsewhere in the grid.

\section{Stages of Voltage Control}

The overall voltage regulation function can be organized into a hierarchy of three levels. 
- Primary voltage control can be local automatic control, which saves the voltage at the generating bus at a set of points. The task is fulfilled by an automatic voltage regulator (AVR) [44].

- The voltage control of the secondary is an integrated control that is automatic to shorten the actions of local controllers. Hence, it is compact for the addition of reactive power inside a local power network.

- Tertiary voltage control refers to the standard optimization of reactive power flow to the power system.

Figure 8 outlines adequate voltage controls with one unit for generating a power system network. Voltage is controlled by the application and use of ratio-changing equipment such as transformer taps and reactive power control such as capacitors, reactors, static-VAR (Volt-ampere reactive) compensators, generators, and rarely synchronous condensers throughout the transmission system. The system operator controls and monitors the voltage and provides the grid's reactive power requirements. VAR absorption at low-load times is necessary to prevent the voltages from becoming too high. In contrast, VAR production can help prevent voltage levels from getting too low during high-load times [62]. In specific areas, it is more economical to purchase a reactive power support utility from a client or producer than to provide immediate reactive support. Dynamic or static VARs can be used to preserve or deliver the units (unit, primarily) based on its ability to keep the VAR output rapidly or faster retaining. In VAR, the cost of a dynamic device is much higher than a static device.

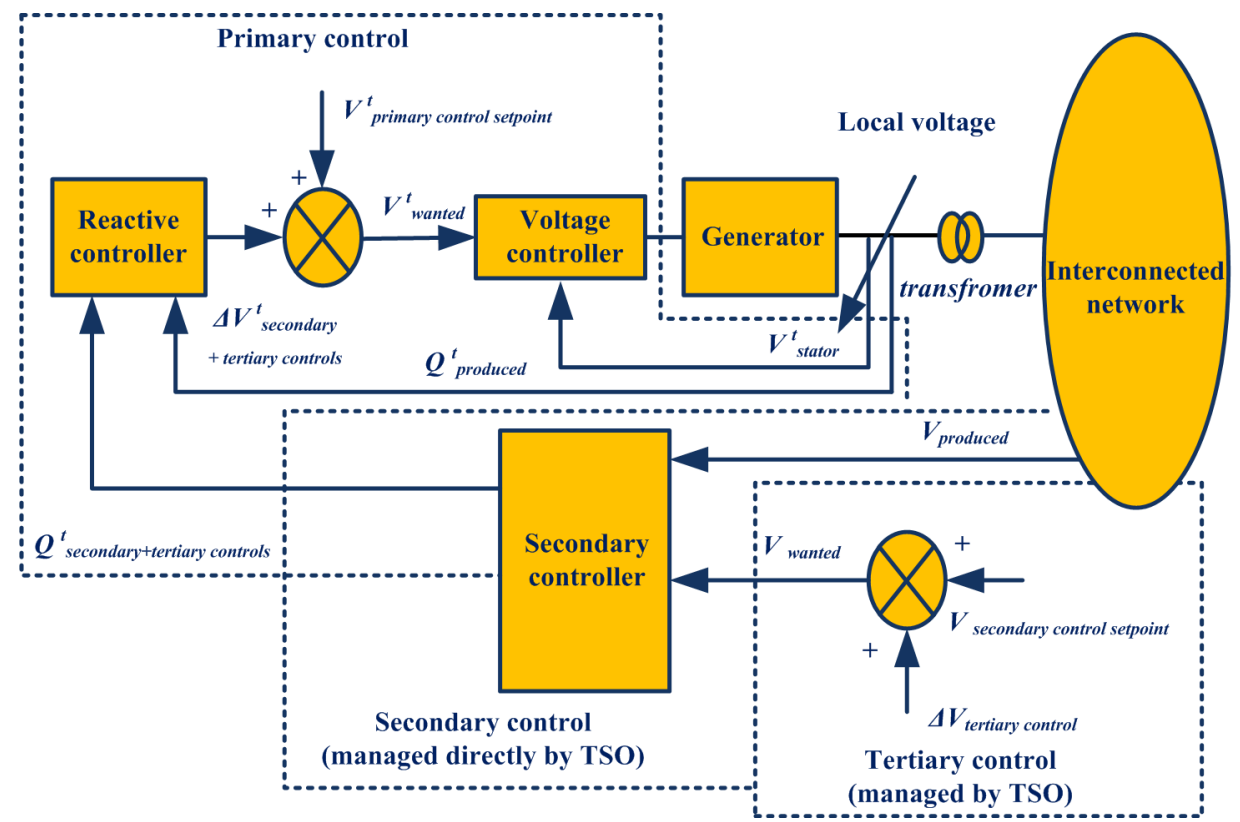

Figure 8. Three functional voltage controls for a generator.

\section{Cost of Voltage Management}

The cost of providing reactive power is mainly the cost of capital for equipment such as generators and capacitors, which can reduce the flow of capital as expected for backup. In addition, reactive support should be allocated to the operating costs of over or under the excitation of generating units. The main cost of generator voltage support is for rotor, stator, exciter, and step-up transformer losses. In some cases, the cost of the opportunity is associated with the loss of VAR production or absorption of real-time power-generation capacity. In the case of reactive power, the actual cost of producing a service can be mostly fixed costs and is usually lumped or isolated. In general, variable cost components are relatively low [43]. 


\subsubsection{Capability of Black Start}

The capability of black start has a characteristic of a black start station, which can start from a shutdown at any cost of its production units and integrate into the system to support a portion of the system and also be coordinated to the system under procedures without having an external power supply. Comparatively, it is termed as a method to energize a system from cases of total or fractional failure. Thus, it must have the generating units with black start ability [63]. The black start unit is measured as a generating unit, which can be started without power supply or determines the capacity with unit load to operate at a reduced level. Therefore, there is grid separation. It consists of at least one black start unit, such that a generating unit of black start reserve system would be able to energize the power system. Therefore, if there is a power outage in the system, it will provide power to local needs.

Electric supply is required to start all generating stations, except for a few small hydro stations. These stations have required some supply for work consumed in the auxiliary unit. So, the turbo generator is used to help in this process of operation. Usually, batteries provide this supply to small diesel generators. For large diesel generators, it is provided by pressurized air and diesel engines that deliver the start-up supply for gas turbines (start-up supply required for gas stations is usually $2 \%$ of installed capacity and $1 \%$ of hydro stations). Therefore, such a generating unit can be used to energize the subsystem/generating stations [57].

It is essential to satisfy the associated performance standards [63]:

- It can shut its circuit breaker for dead bus based on demand.

- It must be able to keep the frequency under various loads.

- It is capable of having a voltage supply for unstable loads.

- It is optimal to have an output rate within the given time as chosen by the system operator.

\subsubsection{Inertia Response for RES}

In general, when generation plants are connected to the network, RESs that are established as an alternative source of energy in the near future will pose new problems with the power supply quality. However, an adequately managed DG can be very useful in distributed networks to improve service continuity in specific geographical locations [64,65]. High penetration of RESs leads to critical challenges of frequency stability.

Firstly, RESs usually have inertial responses that are weak or non-existent. For instance, a power electronic converter typically connects a variable-speed wind turbine to a network that effectively dissipates wind turbine inertia from reducing transient systems. In addition, solar PV plants do not offer the power system with any inertia response. When traditional sources are replaced with RESs, the inertia of the entire electrical system is reduced [66]. Subsequently, an increase in the RES penetration rate reduces the number of manufacturing units that provide primary and secondary control reserve power. For this reason, as explained in [67] and shown in Figure 9, the frequency variance will be increased. The RESs need to create new frequency control techniques to enable them to participate in frequency regulation operations to overcome the frequency stability challenges posed by the small inertial response and reserve power.

Figure 9 shows the typical frequency response with operating limits. The machine frequency is about $50 \mathrm{~Hz}$ during normal operations. However, when an event triggers an imbalance in generation and demand, the frequency of the system begins to decline with the frequency levels, relying on the total system inertia and total unbalanced energy, as shown in the swing formula [68]:

$$
\frac{d f}{d t}=\frac{f_{o}}{2 H_{s y s} S_{B}}\left(P_{m}-P_{e}\right)
$$

where $d f / d t$ is the frequency shift speed, $H_{s y s}$ is the maximum inertia constant of the unit, $S_{B}$ is the rating of generator power, $P_{m}$ and $P_{e}$, are the mechanical power and electrical power, and $f_{o}$ is the frequency of the system. The synchronous generator releases kinetic energy stored in its spinning mass 
before any controller activation and up to $\sim 10 \mathrm{~s}$ [69] due to the inertia reaction. After that, the primary frequency controller is activated immediately if the frequency deviation exceeds a certain value.

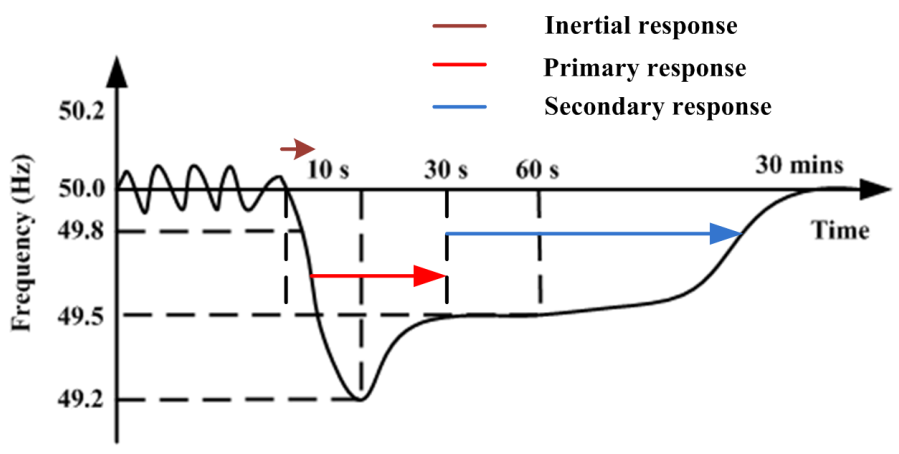

Figure 9. Time stages involved in responding to system frequency [67].

Using the generator governor, this controller returns the frequency to store values in $30 \mathrm{~s}[70,71]$. To restore the system frequency to its nominal value, a new control called secondary control will be triggered after the $30 \mathrm{~s}$. As illustrated in Figure 9, it takes several minutes for the secondary controller to restore the system frequency to its nominal value. Backup capacity is sufficient at this time to cover the increase in power demands. Finally, it enables the control of the tertiary frequency control by residual power deviation. Unlike primary and secondary controllers, the tertiary controller requires manual adjustment when generators are dispatched or scheduled timing adjustments [71]. Frequency and inertial control methods for RES are generally divided into two main categories: RES control techniques without any ESS assistance and RES control techniques with ESS. In Table 5, the frequency/inertia command merits and demerits for RES with and without ESS are illustrated.

Table 5. Merits and demerits of frequency/inertia control for RES (Renewable Energy Sources) with and without ESS [72].

\begin{tabular}{|c|c|c|c|c|}
\hline ESS & Source Type & Methods & Merits & Demerits \\
\hline \multirow[t]{3}{*}{ Without } & Solar & Deloading & $\begin{array}{c}\text { Additional element is not required. } \\
\text { Inertia and frequency regulation } \\
\text { are provided. }\end{array}$ & $\begin{array}{l}\text { It loses some energy } \\
\text { percentage. } \\
\text { It depends on the } \\
\text { conditions of the } \\
\text { environment. }\end{array}$ \\
\hline & Wind & Inertial Response & $\begin{array}{l}\text { Power obtained from the } \\
\text { rotating mass } \\
\text { directly. }\end{array}$ & $\begin{array}{l}\text { The second drop in } \\
\text { frequency may } \\
\text { occur in losses. }\end{array}$ \\
\hline & & Deloading & $\begin{array}{l}\text { Primary frequency control } \\
\text { is provided. }\end{array}$ & $\begin{array}{c}\text { It loses some energy } \\
\text { percentage. }\end{array}$ \\
\hline With & Solar & $\begin{array}{l}\text { Deloading } \\
\text { MPPT }\end{array}$ & $\begin{array}{l}\text { The system is highly effective. } \\
\text { Removes instabilities in power. }\end{array}$ & $\begin{array}{l}\text { Higher cost due to the price of the battery } \\
\text { and lose some energy. } \\
\text { If the battery is fully charged, it fails to } \\
\text { absorb power } \\
\text { from the } \\
\text { grid. }\end{array}$ \\
\hline
\end{tabular}

\subsubsection{FRT and Reactive Power Support}

The radical climate variations caused by global warming and rising demand for energy have led to the development of renewable energy worldwide. Among other RES, wind energy is a pioneer and has grown both in terms of capacity and adopting technology. Wind power generation has changed over the past 30 years, including changes in electrical and mechanical systems, control methods used, and requirements for power system integration [73]. 
FRT capability during transient conditions and reactive power control during stable-state conditions pose considerable challenges for variable speed wind turbines [74] among the new grid code for wind energy grid integration. During faults and voltage sag conditions, wind farms are no longer allowed to disconnect but are expected to function as conventional power plants, provide the support for reactive power and be connected during system failures [75]. The grid code requirement (GCR) for FRT determines the time of fault $\left(T_{\text {fault }}\right)$, permitted fault voltage $\left(V_{\text {fault }}\right)$, recovery time $\left(T_{\text {rec }}\right)$, voltage to be recovered within recovery time $\left(\mathrm{V}_{\text {rec }}\right)$, and the prescribed duration or settling time $\left(\mathrm{T}_{\text {set }}\right)$, as shown in Figure 10.

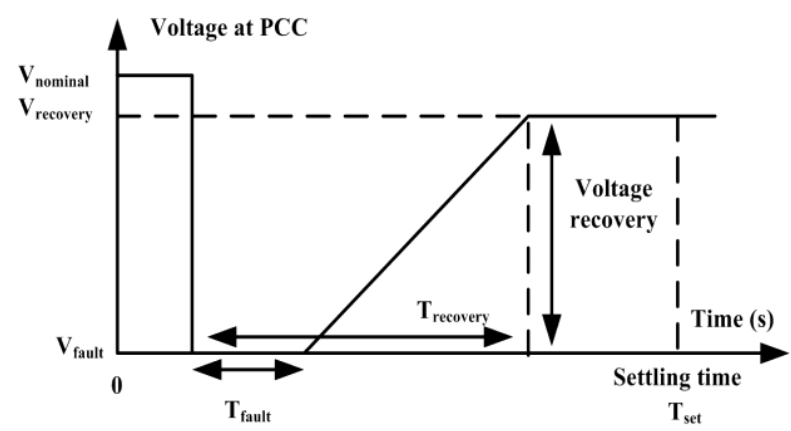

Figure 10. Basic FRT (fault ride-through) capability profile.

After clearance of the fault, $T_{\text {set }}$ will indicate the voltage recovery to the nominal voltage $\left(V_{\text {nom }}\right)$ prefault condition. The ability to return to the standard wind generator operating state assesses the determination of the power system under unstable conditions. The FRT requirements also require the increased injection of reactive current when the voltage is low, as shown in Figure 11. In response to severe voltage drop, reactive current assistance should be achieved within $20 \mathrm{~ms}$ after failure is detected.

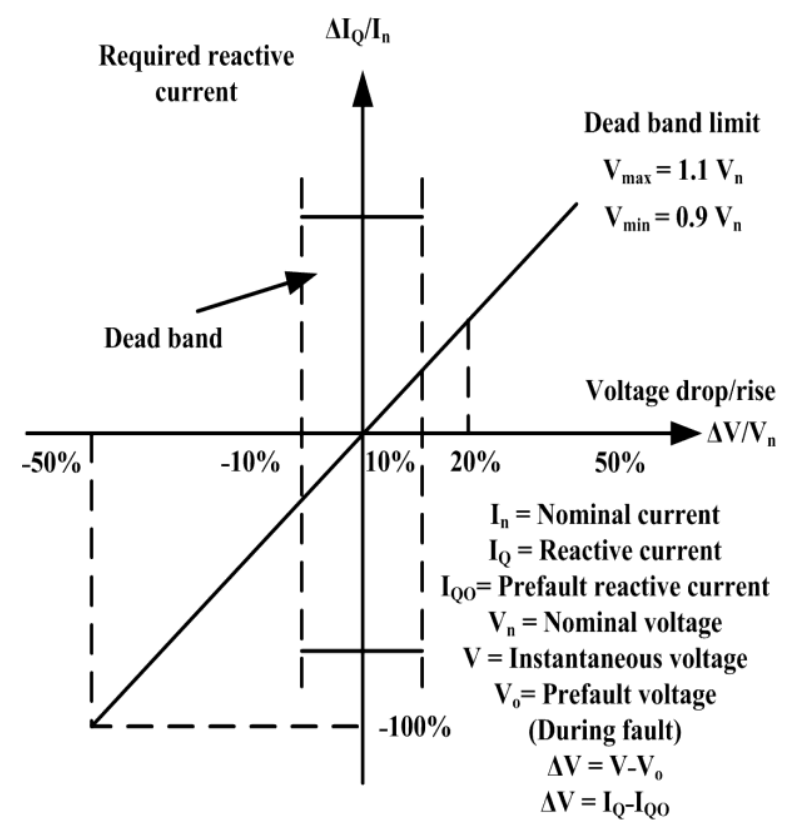

Figure 11. Required reactive current profile based on grid code of E.ON [76].

Double-fed induction generator wind turbines (DFIGWTs) are popular for WT technology. DFIG is an innovative type of variable wind speed generator. However, DFIGWTs can cause disturbances in the grid voltage. They use both the rotor-side converter (RSC) and the control of the grid-side converter (GSC) [77]. The RSC controls maximum power capture by control of rotor rpm and GSC controls the 
active and reactive power supplied and maintains a constant DC-link voltage. The voltage at the fault event also fails to zero and the active power output decreases, which rapidly increases the current of the rotor in an attempt to compensate for the active power of the RSC. The converter then raises the voltage of the rotor, resulting in a high voltage in the DC connection, and DFIG rapidly loses internal magnetization in proportion to the voltage loss. Demagnetization induces high out-rush/over-current currents on both stator and rotor circuits that are greater than the converter's ratings [78]. This leads to the WT connected to the grid being tripped.

Consequently, the GCR suggests the ability of the FRT to ensure continuous operation and prevent excessive power loss due to defects, promoting grid recovery during fault and minimizing problems with resynchronization after fault clearing by reactive power support [79]. The merits and demerits of protection methods during the FRT process are presented in Table 6.

Table 6. Merits and demerits of control techniques using for FRT.

\begin{tabular}{cccc}
\hline Reference & Using Technique & Merits & Demerits \\
\hline$[80]$ & Crowbar & $\begin{array}{c}\text { Activated in the event of failures and } \\
\text { prevents RSC from overload. }\end{array}$ & $\begin{array}{c}\text { When crowbar is applied, RSC control } \\
\text { is lost. }\end{array}$ \\
\hline [81] & SGSC & $\begin{array}{c}\text { Damping synchronous stator frame flux } \\
\text { oscillations and allowing the stator flux } \\
\text { variable to be handled directly. }\end{array}$ & $\begin{array}{c}\text { Weaknesses in preserving the power } \\
\text { balance of the DC-link. }\end{array}$ \\
\hline ESS & $\begin{array}{c}\text { Improves DFIG's transient dynamics } \\
\text { and power systems' transient stability. } \\
\text { DFIG's steady-state active power } \\
\text { output is regulated. }\end{array}$ & $\begin{array}{c}\text { Loss of stored energy in the form of } \\
\text { self-discharges when not in use. }\end{array}$ \\
\hline MSDBR & $\begin{array}{c}\text { This method prevents the use of both } \\
\text { the crowbar and the DC chopper. } \\
\text { Series compensation system and } \\
\text { includes power evacuation. }\end{array}$ & $\begin{array}{c}\text { The injection efficiency of reactive } \\
\text { energy is not yet studied. } \\
\text { Compared to the above techniques, } \\
\text { the value is quite higher. }\end{array}$ \\
\hline
\end{tabular}

\subsubsection{ESS in Congestion Management and Economical Scheduling}

Existing congestion management systems (CMSs) typically determine the transmission point day-ahead stage, the generation process, and the ability to anticipate demand at this level [83]. High penetration of DER in smart distribution systems may lead to network congestion and voltage problems. The establishment of the power distribution market is a good tool for effectively and efficiently managing large amounts of DERs in distribution networks. Active customers and utilities can use this distribution-level market to realize their potential value in distribution grids. A well-designed market could also encourage rational deployment and investment in future planning of new DERs. Therefore, the main goal of market integration is to develop international markets in real time, accepting all network limitations [84]. Therefore, effective CMS should be fully integrated with intraday and stabilization market design. As mentioned earlier, the following are the five key elements to establishing a dynamic CMS:

- $\quad$ Efficient national CMS and integrated with international CMS to get complete utilization of current transmission capacity.

- Combined distribution of global transmission capability, for the flexible usage of transmission capacity where it is more required at a day-ahead level.

- The day-ahead energy market integrated with transmission allocation is the ability to make complete usage of low-cost distribution possibilities.

- The flexible operation across the power system, improvement in RES forecasts such as solar/wind, and other uncertainties in a day is possible with the integration of transmission distribution with the day-ahead energy market. 
A precise method for CMS accepts the efficient support and reliable evaluation of future congestion designs for private and public outcome makers to monitor the investment options. The day-ahead economic scheduling of ESS is the regulating of electricity market positions. The ESS integrates with residential customers in a low voltage generation grid and PV generation, whereas the objective is to expand the revenues from energy arbitrage in day-ahead auction [85]. The internal model of the ESS design addresses the charging/discharge process limitations. Therefore, the PV generation, residential load, price of the market, and formulated constrained optimization challenge minimize the cost function. It mainly focuses on system efficiency, which significantly affects economic performance due to energy losses in the period of charging/discharging cycle.

The integrated PV and ESS play an important role in demand-side management (DSM) activities, and these improvements can influence the performance of electric power systems (EPSs). The market can exist in the wholesale trade of electricity segment and it was developed for energy exchange to handle the day-ahead auction markets. Thus, ESS combining with uncertainty sources for day-ahead economic optimization is a compelling research topic in the economic scheduling operation process. In [86], the authors proposed an hourly discretized optimization algorithm for a residential consumer, PV generation, and a distributed BESS. In this context, the aim was not only on the residential generation, but also on regional stages, where the BESS performed for day-ahead scheduling can improve revenues from energy arbitrage and is subject to the technical constraints of the supply network and storage system. The summary of the MG components and corresponding ancillary services are illustrated in Table 7 [87].

Table 7. Summary of corresponding ancillary services for MG components.

\begin{tabular}{cc}
\hline MG Components & Ancillary Services To Main Grid \\
\hline All DERs, WTGs, PV systems, hydro power plants, and loads with ESSs \\
units but not thermal-driven CHP \\
$\begin{array}{c}\text { Inverter and SG coupled DG/ESS units and loads but not IG coupled DG } \\
\text { WT's coupled with inverters, SGs, PV with inverter, Micro-hydro with } \\
\text { inverter/SG and ESS } \\
\text { WT's with DFIG/Inverter, PV with Inverter, Micro-hydro with Inverter, } \\
\text { CHP with inverter, ESS }\end{array}$ & Frequency regulation \\
\end{tabular}

Further approaches based on the location of the economic evaluation of the specified application and the feasibility study of the ESS were investigated in [88]. The authors illustrated in [89] complete analysis for a day-ahead market of the European power exchange group, an exchange for power spot transactions in Germany, Switzerland, Austria, and France. This study evaluated the corresponding economic evaluation for the possibility of energy arbitrage function in global markets. The key drivers for improvement of ESS solutions are the market prospects over the provision of ancillary services; energy arbitrage; improving the efficiency of transmission, generation, and distribution; and several balancing applications.

\subsubsection{Energy Management System}

To assess an ancillary service technology of a MG, first the grid connection technology and then the entire controlled DER must be analyzed [87]. The economic framework for supplying ancillary services through MG is based on the energy management system (EMS) decision-taking capability, which provides the most promising technology for ancillary services, the most feasible service for community MG owners to generate incremental revenues, and provides security of supply to customers.

As shown in Figure 12, this EMS controls MG power flows through adjustment of power imports/exports from/to the main grid, regulates dispatchable DERs and controls loads based on current information, the generation, and loads to achieve certain operational targets (for example cost reduction) and optimizations of the end of the market. In the case of many ancillary services, the EMS determines whether and at what price it will provide the service in a day-to-day market. The EMS then bids into the market and sees whether the bid is successful. If this service is successful, EMS plans 
to provide it the next day. Therefore, MG owners can benefit from the ancillary services market as the main source of income. MG owners benefit from the energy markets in many parts of the world. Finally, Table 8 summarizes the current and possible ESS facilities for different application areas.

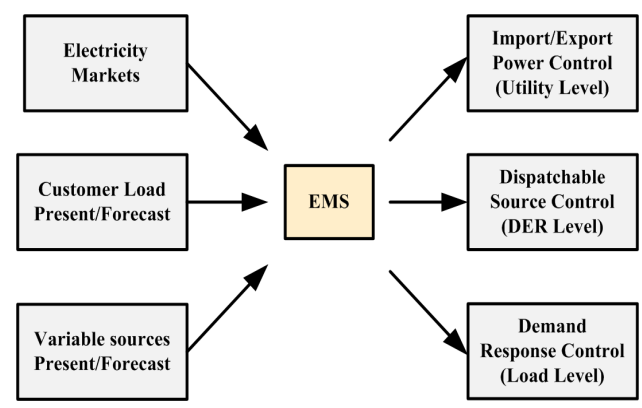

Figure 12. Functions of EMS (energy management system) for MG.

Table 8. Overview of current and possible ESS options with their specifications for different applications [90].

\begin{tabular}{|c|c|c|c|}
\hline Application Area & Summary & $\begin{array}{l}\text { Characteristics and } \\
\text { Specifications }\end{array}$ & ESS Technology Options \\
\hline Power quality & $\begin{array}{l}\text { The issue of Power Quality (PQ) is one of MG's major } \\
\text { technical challenges. The PQ level of the MG network } \\
\text { must be analyzed and quantified to provide a better PQ of } \\
\text { the energy provision. } \\
\text { In both the on grid and off grid mode of MG operation, } \\
\text { voltage and frequency variation are analyzed under } \\
\text { different generation and load conditions. } \\
\text { In order to achieve a better quality of power supply in the } \\
\text { MG system, the level of PQ impact in the MG network } \\
\text { must be quantified in various scenarios. }\end{array}$ & $\begin{array}{c}\sim<1 \mathrm{MW}, \\
\text { Response time: } \sim \mathrm{ms}, \\
\text { Discharge period: } \mathrm{ms} \text { to } \mathrm{s}\end{array}$ & $\begin{array}{l}\text { Exp: FES, BES, SMES SCs; } \\
\text { Pro: FBs }\end{array}$ \\
\hline $\begin{array}{l}\text { RES power } \\
\text { integration }\end{array}$ & $\begin{array}{l}\text { The intermittent generation of renewables can be backed } \\
\text { up, stabilized, or supported by integration with ESS. }\end{array}$ & $\begin{array}{l}\sim 100 \mathrm{~kW}-40 \mathrm{MW}<1 \mathrm{MW} \\
\text { Response time: } \sim \mathrm{s} \text { to min, } \\
\text { Discharge period: up to days }\end{array}$ & $\begin{array}{l}\text { Exp: FES, BES; } \\
\text { Pro: PHES, CAES, FCs }\end{array}$ \\
\hline Frequency control & $\begin{array}{l}\text { Based on active power control by controlling the } \\
\text { DER output. } \\
\text { Generation is adjusted to load minute by minute to } \\
\text { maintain a specific system frequency in the control area. } \\
\text { The micro-sources (DGs) of MG connected to the grid and } \\
\text { located close to the load pockets are an effective way of } \\
\text { delivering this service. }\end{array}$ & $\begin{array}{c}\text { Up to MW level } \\
\text { Response time: } \sim \mathrm{s} \\
\text { Discharge period: } \mathrm{s} \text { to min }\end{array}$ & $\begin{array}{l}\text { Exp: BES, FBs, CAES } \\
\text { Pro: FES, SCs }\end{array}$ \\
\hline Voltage control & $\begin{array}{l}\text { EPSs dynamically respond to changes in active and } \\
\text { reactive power, thereby influencing the voltage profile and } \\
\text { magnitude of the networks. } \\
\text { Dynamic voltage behavior control can be improved with } \\
\text { the functions of ESS facilities. } \\
\text { Various ESS technologies can be used effectively for } \\
\text { voltage control solutions. }\end{array}$ & $\begin{array}{l}\text { Up to few MW level, } \\
\text { Response time: mins } \\
\text { Discharge period: } \\
\text { Up to mins }\end{array}$ & $\begin{array}{l}\text { Exp: BES, FBs; } \\
\text { Pro: SMES, FES, SCs }\end{array}$ \\
\hline Spinning reserve & $\begin{array}{l}\text { ESSs have spinning reserve functions if the generation (or } \\
\text { load decrease) increases rapidly enough to lead } \\
\text { to contingency. } \\
\text { ESS units should be able to react immediately and to keep } \\
\text { outputs up to a few hours. }\end{array}$ & $\begin{array}{c}\text { Up to MW level, } \\
\text { Response time: } \mathrm{s} \\
\text { Discharge period: } 30 \mathrm{~min} \text { to } \\
\text { few hrs }\end{array}$ & $\begin{array}{c}\text { Exp: BES, } \\
\text { Pro: FCs, FBs, FES, } \\
\text { CAES, SMES }\end{array}$ \\
\hline Load levelling & $\begin{array}{l}\text { Load-levelling is a way to balance large fluctuations in } \\
\text { electricity demand. } \\
\text { Traditional batteries and FBs should reduce overall costs } \\
\text { and improve cycling time with peak shaving applications } \\
\text { as well as in load following and time-shifting. }\end{array}$ & $\begin{array}{l}\text { Several hundreds of } \\
\text { MW level, } \\
\text { Response time: mins } \\
\text { Discharge period: } \\
\sim 12 \mathrm{~h} \text { and even more }\end{array}$ & $\begin{array}{l}\text { Exp: BES, PHES, CAES; } \\
\text { Pro: FCs, FBs, TES }\end{array}$ \\
\hline FRT capability & $\begin{array}{l}\text { There has been much interest in the concept of MGs } \\
\text { recently. As the power capacity of MGs increase, EPS can } \\
\text { deliver significant power from DGs. During power grid } \\
\text { interruptions, a high-powered MG disconnect can lead to } \\
\text { power grid instability. } \\
\text { New grid codes that address stringent requirements. } \\
\text { However, broadly linking MGs through distribution } \\
\text { networks requires a change in their philosophy of } \\
\text { connecting them to the utility grid. } \\
\text { Grid-connected MG requires FRT capabilities and ancillary } \\
\text { services during abnormal grid operations. }\end{array}$ & $\begin{array}{l}\text { 100 kW-100 MW } \\
\text { Response time: } \\
\text { Up to } \sim \mathrm{s}, \\
\text { Discharge period: } \mathrm{s} \text { to mins } \\
\text { and even hrs }\end{array}$ & $\begin{array}{l}\text { Exp: BES, FBs, CAES; } \\
\text { Pro: FCs, FES, SCs }\end{array}$ \\
\hline
\end{tabular}


Table 8. Cont.

\begin{tabular}{|c|c|c|c|}
\hline Application Area & Summary & $\begin{array}{l}\text { Characteristics and } \\
\text { Specifications }\end{array}$ & ESS Technology Options \\
\hline $\begin{array}{l}\text { Transmission and } \\
\text { distribution } \\
\text { stabilization }\end{array}$ & $\begin{array}{l}\text { To control power quality, reduce congestion, and/or ensure } \\
\text { that the system operates under normal working } \\
\text { conditions, ESS can be used to synchronize the operation } \\
\text { of a power transmission line or parts of a distribution unit. } \\
\text { Such applications require immediate response and a } \\
\text { relatively large grid demand power capacity. }\end{array}$ & $\begin{array}{l}\text { Up to } 100 \mathrm{MW} \text { level, } \\
\text { Response time: } \sim \mathrm{ms} \\
\text { Discharge period: } \mathrm{ms} \text { to } \mathrm{s}\end{array}$ & $\begin{array}{l}\text { Exp: BES, SMES; } \\
\text { Pro: FBs, FES, SCs }\end{array}$ \\
\hline Black-start & $\begin{array}{l}\text { ESS can deliver a system from a shutdown condition to its } \\
\text { start-up without using electricity from the grid. }\end{array}$ & $\begin{array}{l}\text { Up to } \sim 40 \text { MW level, } \\
\text { Response time: } \\
\quad \sim \text { mins, } \\
\text { Discharge period: } \mathrm{s} \text { to } \mathrm{h}\end{array}$ & $\begin{array}{l}\text { Exp: BES, CAES, FBs; } \\
\text { Pro: FCs, TES }\end{array}$ \\
\hline Standing reserve & $\begin{array}{l}\text { ESS facilities serve as temporary additional generating } \\
\text { units in the middle to large scale grid to balance power } \\
\text { supply and demand at a certain time. } \\
\text { The standing reserve can be used to meet current demand } \\
\text { that is higher than future demand and/or plant failure. }\end{array}$ & $\begin{array}{l}\text { 1-100 MW level, } \\
\text { Response time: }<10 \mathrm{~min}, \\
\text { Discharge period: } \\
\sim 1-5 \mathrm{~h}\end{array}$ & $\begin{array}{c}\text { Exp: BES; } \\
\text { Pro: FCs, FBs, PHES, CAES }\end{array}$ \\
\hline Load following & $\begin{array}{l}\text { ESS installations can support subsequent electricity } \\
\text { demand load changes. } \\
\text { The Irvine Smart Grid Demonstration test project with } \\
\text { advanced batteries offers load follow-up and voltage } \\
\text { support services in California. }\end{array}$ & $\begin{array}{l}\text { Up to hundreds of MW level, } \\
\text { Response time: } \\
\text { up to } \sim 1 \mathrm{~s}, \\
\text { Discharge period: min to } \\
\text { few hours }\end{array}$ & $\begin{array}{l}\text { Exp: FBs, BES, SMES; } \\
\text { Pro: FCs }\end{array}$ \\
\hline EMS & $\begin{array}{l}\text { In EMS, ESS plays an important role in optimizing the use } \\
\text { of energy, and decoupling generation time and } \\
\text { energy consumption. } \\
\text { Typical EMS applications are time-shifting and } \\
\text { peak shaving. }\end{array}$ & $\begin{array}{l}\text { 100 MW for large scale, } \\
\sim 1-100 \text { MW for } \\
\text { medium/small scale } \\
\text { Response time: mins, } \\
\text { Discharge period: hrs } \\
\text { to days }\end{array}$ & $\begin{array}{l}\text { Exp: Large-HS, CAES, TES; } \\
\text { Smal-BES, FBs, TES } \\
\text { Pro: FCs, FES }\end{array}$ \\
\hline Time-shifting & $\begin{array}{l}\text { It can be attained by stored electrical energy when it is } \\
\text { cheaper, and the stored energy used or sold during } \\
\text { periods of high demand. }\end{array}$ & $\begin{array}{l}\text { 1-100 MW \& even more } \\
\text { Response time: mins, } \\
\text { Discharge period: } \\
\sim 3-12 \mathrm{~h}\end{array}$ & $\begin{array}{l}\text { Exp: PHS, CAES, BES; } \\
\text { Pro: FBs, FCs, TES }\end{array}$ \\
\hline Peak shaving & $\begin{array}{l}\text { Peak shaving is the use of stored energy during off-peak } \\
\text { periods to offset energy generation over maximum power } \\
\text { demand periods. } \\
\text { The ESS function offers economic benefits by reducing the } \\
\text { need to use high-cost electricity generation. }\end{array}$ & $\begin{array}{l}\sim 100 \mathrm{~kW}-100 \mathrm{MW} \& \text { even } \\
\text { more } \\
\text { Response time: mins, } \\
\text { Discharge period: hr level, } \\
\sim<10 \mathrm{~h}\end{array}$ & $\begin{array}{l}\text { Exp: PHS, CAES, BES } \\
\text { Pro: FCs, TES }\end{array}$ \\
\hline Network stability & $\begin{array}{l}\text { Some grid/network power electronic, information and } \\
\text { communication systems are highly vulnerable to } \\
\text { fluctuations in power. } \\
\text { ESS installations can provide the protective function for } \\
\text { these systems, requiring high ramp power and high } \\
\text { cycling time capabilities with a rapid response time. }\end{array}$ & $\begin{array}{l}\text { Up to MW level, } \\
\text { Response time: } \mathrm{ms}, \\
\text { Discharge period: Up to ms }\end{array}$ & $\begin{array}{c}\text { Exp: BES FES, SCs, SMES; } \\
\text { Pro: FBs }\end{array}$ \\
\hline
\end{tabular}

The evolution and development of ESS technology will be possible with advanced control methods to mitigate the abovementioned problems. It not only depends on the enhancement in characteristics of energy storage, system control, and management strategy, but also requires the cost minimization and supports for long-term supplies, a positive stable market, and a plan to control and sustain the healthy development of the ESS industry.

\subsection{Global Prospects on Ancillary Services}

Ancillary services usually include operational reserve, regulation of frequency, and also considerably faster response. Great Britain operators include the mandatory ancillary services such as frequency response, black start, reactive power, load following, reserve capacity, and demand turn up and intertrip [91]. The ancillary services are mostly supported by power plants or large, pumped, hydro storage systems [92]. It was found that there is no standardized classification of ancillary services. Several ancillary services are recognized around the globe based on the power system network and regional requirements. As per Eurelectric [93], the frequency and voltage control and system stability can be considered as ancillary services. It has been reported by CIGRE (International Council on Large Electric Systems) that voltage, frequency control, network control, and black start are the required ancillary services [94]. FERC (Federal Energy Regulatory Commission) in the U.S. describes the need for services to support the production of electricity from seller to consumer, while 
maintaining a consistent process of coordinated communication. The FERC recognizes six vital ancillary services that should be included in open access transmission tariff [95]: (1) scheduling, system control, and dispatch, (2) frequency regulation, (3) energy imbalance, (4) volt/VAR (Volt-ampere reactive) control from generation sources, (5) operating reserve-spinning reserve, and (6) operating reserve-supplemental reserve.

The Canadian electricity board specified that the services are mandatory to control for operation of the interconnected generation system and that the voltage and frequency regulations require acceptable control limits [96]. Table 9 summarizes some of the popular ancillary services available in the main and large power systems of the world. Power systems in many countries are operated by similar or different operators at the regional level. Therefore, there may be different set/subset services in different parts of the same country.

Table 9. Available ancillary services around the world.

\begin{tabular}{|c|c|c|c|c|c|c|c|c|c|c|c|c|c|c|c|}
\hline Ref. & AS/Country & SR & $\mathrm{TC}$ & TMR & VS & DTI & BS & SuR & OR & SR & EB & FC & S/D & VARC & VC \\
\hline [97] & $\mathrm{CN}$ & & & & & & $\checkmark$ & & & $\checkmark$ & & $\checkmark$ & $\checkmark$ & $\checkmark$ & $\checkmark$ \\
\hline [71] & US & & & & & & & $\checkmark$ & & $\checkmark$ & $\checkmark$ & $\checkmark$ & $\checkmark$ & $\checkmark$ & $\checkmark$ \\
\hline [98] & IN & & & & & & $\checkmark$ & & $\checkmark$ & $\checkmark$ & & $\checkmark$ & $\checkmark$ & $\checkmark$ & $\checkmark$ \\
\hline [42] & RU & & & & & & $\checkmark$ & & & & $\checkmark$ & $\checkmark$ & & $\checkmark$ & $\checkmark$ \\
\hline [99] & $\mathrm{JP}$ & & & & $\checkmark$ & & $\checkmark$ & & $\checkmark$ & $\checkmark$ & $\checkmark$ & $\checkmark$ & $\checkmark$ & $\checkmark$ & $\checkmark$ \\
\hline [71] & $\mathrm{CD}$ & & & $\checkmark$ & & $\checkmark$ & $\checkmark$ & & & $\checkmark$ & & $\checkmark$ & & $\checkmark$ & $\checkmark$ \\
\hline [100] & GE & $\checkmark$ & & & $\checkmark$ & & $\checkmark$ & $\checkmark$ & & & $\checkmark$ & $\checkmark$ & $\checkmark$ & & $\checkmark$ \\
\hline [101] & $\mathrm{BR}$ & & & & & & & $\checkmark$ & $\checkmark$ & $\checkmark$ & & $\checkmark$ & & & $\checkmark$ \\
\hline [102] & SK & & & & & & $\checkmark$ & $\checkmark$ & & $\checkmark$ & & $\checkmark$ & $\checkmark$ & $\checkmark$ & $\checkmark$ \\
\hline [103] & FR & $\checkmark$ & & & & & $\checkmark$ & & $\checkmark$ & & & $\checkmark$ & & $\checkmark$ & $\checkmark$ \\
\hline [104] & $\mathrm{AU}$ & $\checkmark$ & & & & & $\checkmark$ & & & $\checkmark$ & $\checkmark$ & $\checkmark$ & $\checkmark$ & $\checkmark$ & $\checkmark$ \\
\hline [105] & UK & & & & & $\checkmark$ & $\checkmark$ & & & & & & & & $\checkmark$ \\
\hline [106] & MX & $\checkmark$ & $\checkmark$ & $\checkmark$ & $\checkmark$ & $\checkmark$ & $\checkmark$ & $\checkmark$ & $\checkmark$ & $\checkmark$ & $\checkmark$ & $\checkmark$ & $\checkmark$ & $\checkmark$ & $\checkmark$ \\
\hline [107] & IR & & & & & & $\checkmark$ & & $\checkmark$ & & & $\checkmark$ & $\checkmark$ & $\checkmark$ & $\checkmark$ \\
\hline [108] & SA & $\checkmark$ & & & & & $\checkmark$ & & & $\checkmark$ & & $\checkmark$ & $\checkmark$ & $\checkmark$ & $\checkmark$ \\
\hline [109] & TR & & & & & & $\checkmark$ & $\checkmark$ & $\checkmark$ & & $\checkmark$ & $\checkmark$ & $\checkmark$ & $\checkmark$ & $\checkmark$ \\
\hline
\end{tabular}

Ref., reference; AS, ancillary services; SR, system restoration; TC time correction; TMR, transmission must run; VS, voltage stability; DTI, demand turn-up and intertrip; BS, black start; SuR, supplemental reserve; OR, operating reserve; SR, spinning reserve; EB, energy balancing; FC, frequency control; S/D, scheduling or dispatch; VARC, VAR control; VC, voltage control.

\section{Drivers Involved in MG Development and Deployment}

Earlier, MG was described by the Consortium of Electric Reliability Technology Solutions (CERTS) as a semi-autonomous collection of DGs and controllable loads simultaneously producing a secure and reliable operation to the local community network [110]. MGs incorporate modular DERs such as wind, solar PV, and fuel cells to form a low-voltage distribution system with the help of storage devices and controllable loads [111].

\subsection{Functions of $M G$}

The specific definition of MG cannot be determined easily because the scope and structure of MG may vary. MG is a limited group of multiple low- or medium-voltage distributed generation, load, and storage units that act as a self-coordinated system. MGs have the role of self-healing smart grids in the future as they have an islanding capability to reduce outages. They consist of interrelated, renewable, and conventional energy sources and are often associated with the distribution grid at a point of common coupling (PCC). Therefore, for the DSO (Distribution System Operator) perspective, they can occur as a single, flexible, and controllable entity. There is no definition of the size of MGs, and this may vary, but it is usually considered to be a small part of low or medium voltage distribution network [112]. The process of market participation for MG is shown in Figure 13. 


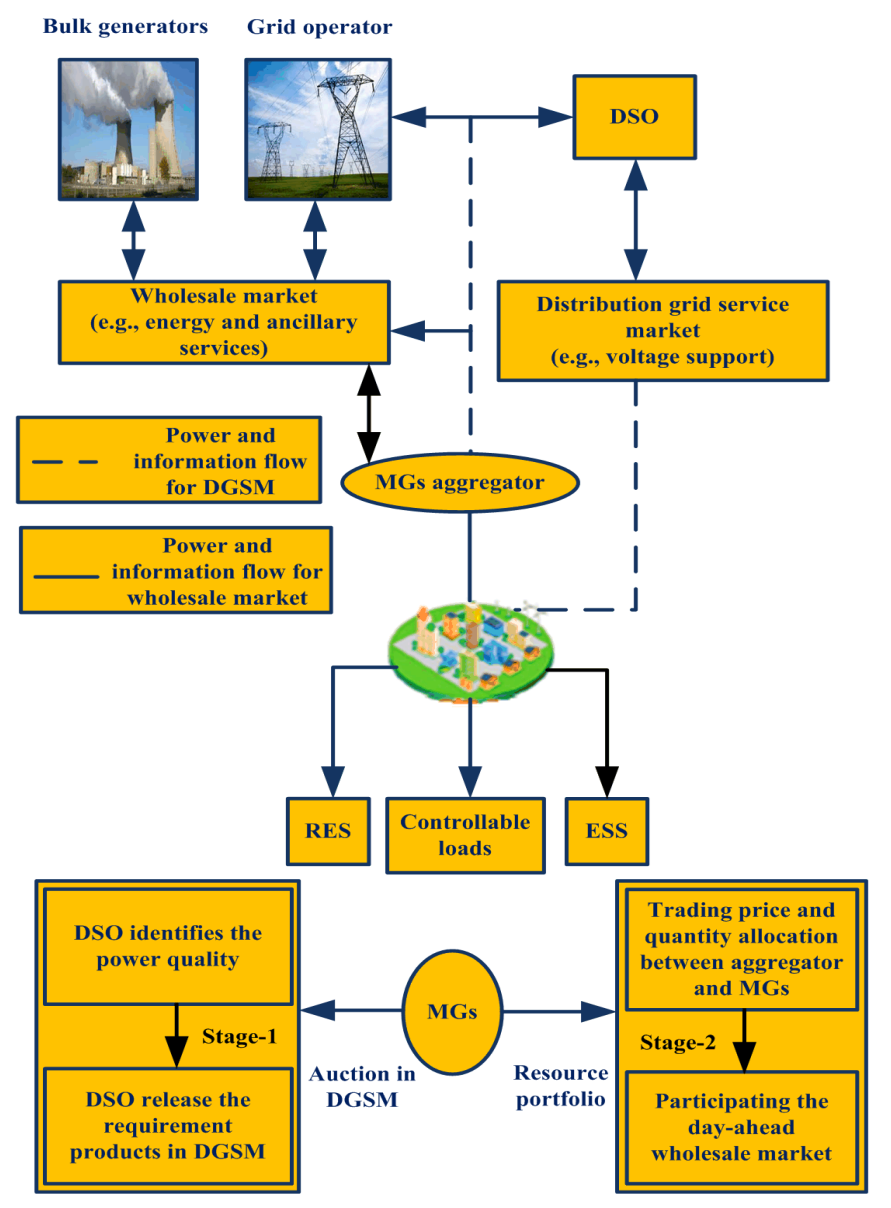

Figure 13. Market participation process for MGs [113].

MGs are key components of the local energy markets and offer the possibility of peer-to-peer energy transactions [114]. To operate, $M G$ requires a variety of components. In simple terms, the foundation of MGs is DERs. This includes DG, storages, or active loads. Second, a physical network is required to connect all DER and consumers. To manage and control distributed energy flows delivered through integrated communication, advanced control and demand response technology is required. The ownerships of MGs can be divided into three different designs. In "DSO monopoly MG", the DSO owns the grid and all the responsibilities and costs of operating the MG come to the operator, but also the benefits. Usually, this occurs in nonliberalized markets, where the DSO includes energy distribution and retail. "Prosumer Consortium MG" has single or multiple customers with different DERs, thus benefiting from lower electricity bills or revenues generated when supplying the grid with surplus electricity. "Free Market MG" is run by different stakeholders such as DSOs, prosumers, or consumers. It means that a central controller has functioned MG. Subsequently, this type of MG is driven by many stakeholders, as well as the profits shared among them [115].

\subsection{Factors Responsible for MG Development}

There are three distinct benefit classes related to MGs: technical, economical, and environmental. From a technical view, some of the benefits include the power distribution to remote communities such as energy enhancement, providing communication support in remote areas, and it will help to reduce the huge power blackouts for networks [40,41]. Commercial interests have been extensively studied [42]. They describe emissions, line losses, customer disruption costs, and fuel price reductions. Conversational support of MGs has been addressed in [43], with MGs ending with less discharge of pollutants and greenhouse gases. Also, the generation system needs a smaller physical footprint. MG consumption also increases the number of clean energy sources integrated into the grid. This reduces 
the dependence on external sources of energy. The aspects of MG driving fall into three broad categories as described in Table 10, below:

- $\quad$ Energy safety measures,

- Economic gains, and

- Clean energy integration.

Table 10. Classification of MG drivers.

\begin{tabular}{|c|c|c|c|c|}
\hline Reference & Category & Driver & Outline & Current Examples \\
\hline [29] & $\begin{array}{l}\text { Energy } \\
\text { Security }\end{array}$ & Severe weather & $\begin{array}{l}\text { It is a known fact that weather might be a greater } \\
\text { disruption, especially in countries like the United } \\
\text { States. This is the reason that climate change will } \\
\text { result in a need to address the resilience of the grids. } \\
\text { Thus, MGs could offer power to major services and } \\
\text { groups through their spread generation assets if the } \\
\text { main drop. }\end{array}$ & $\begin{array}{l}\text { Costs levied on-grid outage concerning } \\
\text { weather-related issues in the U.S. alone } \\
\text { between 2003-12 ranging around } \\
\text { \$18B-\$33B in a year due to poor output and } \\
\text { wages disposal, also from spoiling } \\
\text { inventory, delayed production followed by } \\
\text { losses from the electric grid [29]. }\end{array}$ \\
\hline [117-125] & & $\begin{array}{l}\text { Physical and } \\
\text { Cyber outbreaks }\end{array}$ & $\begin{array}{l}\text { Today, the grid depends on progressive information } \\
\text { and communications technologies, thus making it } \\
\text { susceptible to cyber-attack [117]. The central grid } \\
\text { network involves larger components, which are rather } \\
\text { costly and difficult to exchange whenever they get } \\
\text { damaged. MGs, with the decentralized design, are less } \\
\text { susceptible to outbreaks on distinct sections of } \\
\text { generation or transmission power supplies, natural } \\
\text { [118,119], artificial, or electromagnetic pulse incidents } \\
\text { might also under disastrous results [120,121]. }\end{array}$ & $\begin{array}{l}\text { Ukrainian cyber-attacks [122] in } 2015 \text { and } \\
\text { Israel in } 2016 \text { were effectively } \\
\text { eliminated [123]. } \\
\text { Larger transformers were confronted at a } \\
\text { major California substation in } \\
2013[124,125] .\end{array}$ \\
\hline [126-128] & & $\begin{array}{l}\text { Saving the cost of } \\
\text { infrastructural facilities }\end{array}$ & $\begin{array}{l}\text { U.S. electricity grid systems were not able to keep up } \\
\text { with the generation pace. Consequently, the capacity } \\
\text { of the grid is inhibited in several zones, and } \\
\text { components are relatively old, with } 70 \% \text { transmission } \\
\text { lines and transformers now moving forward to } 25 \\
\text { years. The age of the power plant is over } 30 \text { years } \\
\text { old [126]. It has the capability of avoiding or deferring } \\
\text { investments for replacement. }\end{array}$ & $\begin{array}{l}\text { The deferred construction over } \$ 1 \mathrm{~B} \\
\text { substation from Queens and the Brooklyn } \\
\text { area of NY [127]. } \\
\text { Costs levied } \$ 40,000-\$ 100,000 \text { per mile, } \\
\text { relying based on prominent factors like } \\
\text { terrain, design, and cost of labor of building } \\
\text { new primary distribution systems [128]. }\end{array}$ \\
\hline$[129,130]$ & & Fuel Savings & $\begin{array}{l}\text { MGs provide various efficiency types, including } \\
\text { minimizing losses in the line, the combination of heat, } \\
\text { cooling, and power losses, along with the shift to } \\
\text { distribution systems of direct current to remove } \\
\text { unnecessary DC-AC conversions. When absorption } \\
\text { cooling technology with the combination of heat and } \\
\text { power applications might aid in addressing the peak } \\
\text { electricity demand that usually occurs in the summer } \\
\text { season [130]. }\end{array}$ & $\begin{array}{l}\text { The losses from wastage in transmission } \\
\text { and distribution are about } 5 \% \& 10 \% \text { over a } \\
\text { gross electricity generation [129]. } \\
\text { When appropriately used, the effectiveness } \\
\text { of heat and power systems can reach } \\
80-90 \% \text { [108], which is found to be much } \\
\text { higher than the average efficiency of the } \\
\text { U.S. grid that is currently (only } \sim 30-40 \% \text { ) } \\
\text { used [129,130]. }\end{array}$ \\
\hline [131-135] & & Ancillary Services & $\begin{array}{l}\text { Conventional ancillary services consist of relief from } \\
\text { congestions, regulation of frequency \& load, black start, } \\
\text { controlling both reactive power \& voltage along with } \\
\text { spinning supplies. This is because of their capability to } \\
\text { provide the same inertia as that of a conventional } \\
\text { power generation system, non-spinning, and } \\
\text { additional reserves [131,132]. Also, all the individual } \\
\text { operations should be included in the list [133]. }\end{array}$ & $\begin{array}{l}\text { Current rulings under } 755 \text { \& } 784 \text { of U.S. } \\
\text { FERC necessitate the fast-reacting reserves } \\
\text { that are employed in MGs that needs to be } \\
\text { compensated as per their speediness and } \\
\text { accurateness, options for the possibility of } \\
\text { new revenue system }[134,135] \text {. }\end{array}$ \\
\hline [136-141] & $\begin{array}{l}\text { Integration of } \\
\text { the clean } \\
\text { energy system }\end{array}$ & $\begin{array}{l}\text { Need to secure } \\
\text { inconstant and } \\
\text { uncontrollable resources }\end{array}$ & $\begin{array}{l}\text { Significant sources for clean energy sources for } \\
\text { addressing climate change such as solar PV and wind } \\
\text { are variable and non-controllable that could result in } \\
\text { challenges such as excessive generation }[136], \text { steep } \\
\text { ramping }[137,138] \text { and voltage control }[139,140] \text { MGs } \\
\text { are designed for handling variable generation by } \\
\text { making use of storage technologies for locally } \\
\text { balancing the generation of loads. }\end{array}$ & $\begin{array}{l}\text { In Texas, California, and Germany, the cost } \\
\text { of electricity is relatively high, } \\
\text { which reflects the imbalance found between } \\
\text { demand and supply }[140,141] \text {. }\end{array}$ \\
\hline
\end{tabular}

\subsection{Application of $M G$}

To integrate DERs, the smart MG is the most effective platform, for example, solar PV, diesel generator, fuel cell, wind turbine, and micro combined heat and power sections. Undefined problems arise from RES for sustainability development at different nodes of MG grid delivery deployed using storage. An ESS utility includes a power-quality controller, which produces the active and reactive power required by clients. The principle of controlling voltage for high loads with load shedding is not sufficient to achieve a higher quality of power supply, which has an effect on MG [99]. 
Therefore, this is an additional advantage of ESSs, which often have the effect of improved energy quality in the MG environment when a fault frequently occurs [142,143]. In addition, ESSs offer a variety of applications [144] such as black start [145,146], power alternation inhibiting [147,148], grid inertia response [149], wind power gradient reduction [150], peak shaving [151,152] and load following [153]. Nowadays, researchers are trying to come up with a number of approaches to develop power management and system stabilization of MGs by using ESS. To integrate resources for MG, storage systems and the power electronic interfaces are discussed in [154]. A cooperative control mechanism for the control of frequency and voltage is discussed in [155], which also helps to reduce the power variation from RESs (such as wind turbines) and stabilize the frequency in the control system and in a wide range of power systems. This suggests the effect of the electromechanical oscillations of the fast response of energy storage in the power system [156]. This helps reduce the short-term variations and minimizes the capacity of the storage system.

\section{Conclusions}

MG technologies have been serving as a key spot in research over distributed energy systems. The core of the continuing development of these services is to ensure that effective compliance systems are in place for security measures, scheduling followed by the design of MG, as well as related issues with regulating and EMS operation for control strategies and ancillary services. The monitoring and evaluation system helps to plan the potential direction for the implementation of new ancillary services as competition grows in this sector. In addition, the underlying prospects of governing ancillary services for smart MG remain a topic of research in detail in this paper. There is a rapid reduction in battery storage costs and solar PV production for a moment close to cost equality with conventional power sources. Therefore, the larger implementation of these systems has accelerated for the assumption of energy at some point, where other customs are concerned with the import and export of electricity with the end user. Previously, DERs were related to the electrical grid, and it was sufficient for the community to identify and design which architectural design would best integrate with distributed technologies. Instead of ensuring the reliability, protection, and stability of renewable sources in microgrids, installing ESSs can also generate substantial revenues through ancillary services to the main grid. With the use of ESS for ancillary services, the overall deployment cost of linked microgrids is decreased. ESS plays an important role in every sector, ensuring the safe, stable, reliable operation of power systems and having a wide range of application capabilities. Smart MGs will achieve this transformation through demand and supply balance, while ensuring reliability and flexibility, as opposed to increasing natural and human-made obstacles. Through an increasing number of small-scale MGs, and by providing the system with the state-of-the-art multimarket framework, it encompasses a large part of the planning process for the real environment. Due to quick response and stability control in MGs, such as voltage and frequency regulation, reactive power injection, supply balance, and demand response, the results of MG can be developed in the market interest of future research directions.

Author Contributions: Conceptualization, methodology, investigation, resources, data curation, writing-original draft preparation, G V B.K.; visualization, supervision, review, and editing, K P. Both authors have read and agreed to the published version of the manuscript.

Funding: This work is supported by the Department of Science and Technology (DST), Government of India (GOI) with the project grant SR/FST/ETI-420/2016(C) under FIST scheme.

Conflicts of Interest: The authors declare no conflict of interest.

\section{Abbreviations}

$\begin{array}{ll}\text { MG } & \text { Microgrid } \\ \text { PV } & \text { Photovoltaic } \\ \text { RES } & \text { Renewable Energy Sources } \\ \text { DER } & \text { Distributed Energy Resources }\end{array}$




$\begin{array}{ll}\text { ESS } & \text { Energy Storage System } \\ \text { DGDG } & \text { Distributed Generation } \\ \text { DSO } & \text { Distribution System Operator } \\ \text { SGSC } & \text { Series Grid Side Converter } \\ \text { VAR } & \text { Volt-ampere reactive } \\ \text { FERC } & \text { Federal Energy Regulatory Commission } \\ \text { NERC } & \text { North American Electric Reliability Corporation } \\ \text { CIGRE } & \text { International Council on Large Electric Systems } \\ \text { UCTE } & \text { Union for the Coordination of Transmission of Electricity } \\ \text { MSDBR } & \text { Modulated Series Dynamic Breaking Resistor } \\ \text { CN } & \text { China } \\ \text { IN } & \text { India } \\ \text { JP } & \text { Japan } \\ \text { GE } & \text { Germany } \\ \text { SK } & \text { South Korea } \\ \text { US } & \text { United States } \\ \text { RU } & \text { Russia } \\ \text { FR } & \text { France } \\ \text { UK } & \text { United Kingdom } \\ \text { BR } & \text { Brazil } \\ \text { IR } & \text { Iran } \\ \text { SA } & \text { South Africa } \\ \text { MX } & \text { Mexico }\end{array}$

\section{References}

1. Levron, Y.; Guerrero, J.M.; Beck, Y. Optimal Power Flow in Microgrids With Energy Storage. IEEE Trans. Power Syst. 2013, 28, 3226-3234. [CrossRef]

2. Liu, X.; Wang, P.; Loh, P.C. A Hybrid AC/DC Microgrid and Its Coordination control. IEEE Trans. Smart Grid. 2011, 2, 278-286. [CrossRef]

3. Duan, C.C.S.; Liu, T.C.B. Smart energy management system for optimal microgrid economic operation. IET Renew. Power Gen. 2011, 5, 258-267. [CrossRef]

4. Guerrero, J.M.; Chandorkar, M.; Lee, T.; Loh, P.C. Advanced Control Architectures for Intelligent Microgrids — Part I: Decentralized and Hierarchical Control. IEEE Trans. Ind. Electron. 2013, 60, 1254-1262. [CrossRef]

5. Molina, M.G. Distributed Energy Storage Systems for Applications in Future Smart Grids. In Proceedings of the 2012 Sixth IEEE/PES Transmission and Distribution: Latin America Conference and Exposition (T\&D-LA), Montevideo, Uruguay, 3-5 September 2012; pp. 1-7. [CrossRef]

6. Force, I.T.; Olivares, C.D.E.; Mehrizi-sani, A.; Etemadi, A.H.; Cañizares, C.A.; Iravani, R.; Kazerani, M.; Hajimiragha, A.H.; Gomis-bellmunt, O.; Saeedifard, M.; et al. Trends in Microgrid Control. IEEE Trans. Smart Grid. 2014, 5, 1905-1919. [CrossRef]

7. Martin-martínez, F.; Rivier, M.A. literature review of Microgrids: A functional layer based classification. Renew. Sustain. Energy Rev. 2016, 62, 1133-1153. [CrossRef]

8. Gundumalla, V.B.K.; Eswararao, S. Ramp Rate Control Strategy for an Islanded DC Microgrid with Hybrid Energy Storage System. In Proceedings of the 2018 4th International Conference on Electrical Energy Systems (ICEES), Chennai, India, 7-9 February 2018; pp. 82-87. [CrossRef]

9. Hirsch, A.; Parag, Y.; Guerrero, J.M. Microgrids: A review of technologies, key drivers, and outstanding issues. Renew. Sustain. Energy Rev. 2018, 90, 402-411. [CrossRef]

10. DeBlasio, D. Toward a self-healing smart grid. Fortnightly Mag. 2013. Available online: https://www. fortnightly.com/fortnightly/2013/08/toward-self-healing-smart-grid (accessed on 20 September 2016).

11. Asmus, P. Microgrids, virtual power plants and our distributed energy future. Electr. J. 2010, $23,72-82$. [CrossRef]

12. Madureira, A.G.; Peças Lopes, J.A. Ancillary services market framework for voltage control in distribution networks with microgrids. Electr. Power Syst. Res. 2012, 86, 1-7. [CrossRef] 
13. Distributed Energy Resources Roadmap for New York's Wholesale Electricity Markets; New York Independent System Operator: New York, NY, USA, 2017.

14. Huang, J.; Jiang, C.; Rong, X. A review on distributed energy resources and Micro Grid. Renew. Sustain. Energy Rev. 2008, 12, 2465-2476.

15. Nick, M.; Cherkaoui, R.; Paolone, M. Optimal Allocation of Dispersed Energy Storage Systems in Active Distribution Networks for Energy Balance and Grid Support. IEEE Trans. Power Syst. 2014, 29, 2300-2310. [CrossRef]

16. Chen, Y.; Hu, M. Balancing collective and individual interests in transactive energy management of interconnected micro-grid clusters. Energy 2016, 109, 1075-1085. [CrossRef]

17. Muruganantham, B.; Gnanadass, R.; Padhy, N.P. Challenges with renewable energy sources and storage in practical distribution systems. Renew. Sustain. Energy Rev. 2017, 73, 125-134. [CrossRef]

18. Coelho, V.N.; Cohen, M.W.; Coelho, I.M.; Liu, N.; Guimarães, F.G. Multi-agent systems applied for energy systems integration: State-of-the-art applications and trends in microgrids. Appl. Energy 2017, 187, 820-832. [CrossRef]

19. Walton, R. Former FERC Chair Says Microgrids Are Key to Grid Security, Util Dive. 2014. Available online: http://www.utilitydive.com/news/former-ferc-chair-says-microgrids-are-key-togrid-security/327814 (accessed on 13 September 2016).

20. Center for Energy, Marine Transportation and Public Policy at Columbia University. Microgrids: An Assessment of the Value, Opportunities and Barriers to Deployment in New York State; New York State Energy Research and Development Authority: Albany, NY, USA, 2010.

21. Tweed, K. New York Looks to Cement Its Lead as Microgrid Capital of the World. 2015. Available online: https://www.greentechmedia.com/articles/read/new-york-looks-to-cement-itslead-as-microgridcapital-of-the-world (accessed on 3 March 2016).

22. Pachauri, R.K.; Allen, M.R.; Barros, V.R.; Broome, J.; Cramer, W.; Christ, R.; Church, J.A.; Clarke, L.; Dahe, Q.; Dasgupta, P.; et al. Climate Change: 2014: Synthesis Report. Contribution of Working Groups I, II and III to the Fifth Assessment Report of the Intergovernmental Panel on Climate Change. IPCC. 2014. Available online: https://epic.awi.de/id/eprint/37530/ (accessed on 1 November 2014).

23. Gamarra, C.; Guerrero, J.M. Computational optimization techniques applied to microgrids planning: A review. Renew Sustain Energy Rev. 2015, 48, 413-424. [CrossRef]

24. Mariam, L.; Basu, M.; Conlon, M.F. Microgrid: Architecture, policy and future trends. Renew. Sustain. Energy Rev. 2016, 64, 477-489. [CrossRef]

25. Díaz-gonzález, F.; Sumper, A.; Gomis-bellmunt, O.; Villafáfila-robles, R. A review of energy storage technologies for wind power applications. Renew. Sustain. Energy Rev. 2012, 16, 2154-2171. [CrossRef]

26. Dragicevic, T.; Vasquez, J.C.; Guerrero, J.M.; Skrlec, D. Advanced LVDC Electrical Power Architectures and Microgrids: A step toward a New Generation of Power Distribution Networks. IEEE Electrif. Mag. 2014, 2, 54-65. [CrossRef]

27. Akorede, M.F.; Hizam, H.; Pouresmaeil, E. Distributed energy resources and benefits to the environment. Renew. Sustain. Energy Rev. 2010, 14, 724-734. [CrossRef]

28. Mekhilef, S.; Saidur, R.; Safari, A. Comparative study of different fuel cell technologies. Renew. Sustain. Energy Rev. 2012, 16, 981-989. [CrossRef]

29. U.S. Department of Energy's Offic. Economic Benefits of Increasing Electric Grid Resilience to Weather Outages, Executive Office of the President; 2013. Available online: https://www.energy.gov/sites/prod/files/2013/08/f2/ Grid\%20Resiliency\%20Report_FINAL.pdf (accessed on 15 December 2020).

30. Hossain, E.; Kabalci, E.; Bayindir, R.; Perez, R. A Comprehensive Study on Microgrid Technology. Int. J. Renew. Energy Res. 2014, 4, 1094-1107.

31. May, G.J.; Davidson, A.; Monahov, B. Lead batteries for utility energy storage: A review. J. Energy Storage 2018, 15, 145-157. [CrossRef]

32. Brahmendra Kumar, G.V.; Palanisamy, K. A Review on Microgrids with Distributed Energy Resources. In Proceedings of the 2019 Innovations in Power and Advanced Computing Technologies (i-PACT), Vellore, India, 22-23 March 2019; pp. 1-6. [CrossRef] 
33. Suvire, G.O.; Mercado, P.E.; Ontiveros, L.J. Comparative Analysis of Energy Storage Technologies to Compensate Wind Power Short-Term Fluctuations. In Proceedings of the 2010 IEEE/PES Transmission and Distribution Conference and Exposition: Latin America (T\&D-LA), Sao Paulo, Brazil, 8-10 November 2010; pp. 522-528. [CrossRef]

34. Rosen, M.A.; Koohi-Fayegh, S. A review of energy storage types, applications and recent developments. J. Energy Storage 2020, 27, 101047. [CrossRef]

35. Kirubakaran, A.; Jain, S.; Nema, R.K. A review on fuel cell technologies and power electronic interface. Renew. Sustain. Energy Rev. 2019, 13, 2430-2440. [CrossRef]

36. Saraiva, J.T.; Gomes, M.H. Provision of Some Ancillary Services by Microgrid Agents. In Proceedings of the 7th International Conference on the European Energy Market, Madrid, Spain, 23-25 June 2010; pp. 1-8. [CrossRef]

37. Lasseter, R.H. MicroGrids. In Proceedings of the IEEE Power Eng. Society Winter Meeting, New York, NY, USA, 27-31 January 2002; pp. 305-308. [CrossRef]

38. Venayagamoorthy, G.K.; Sharma, R.K.; Gautam, P.K.; Ahmadi, A. Dynamic energy management system for a Smart Microgrid. IEEE Trans. Neural Networks Learn. Syst. 2016, 27, 1643-1656. [CrossRef] [PubMed]

39. Su, S.; Li, Y.; Duan, X. Self-organized criticality of power system faults and its application in adaptation to extreme climate. Chin. Sci. Bull. 2009, 54, 1251-1259. [CrossRef]

40. Kumar, A.; Chowdhury, S.P.; Chowdhury, S.; Paul, S. Microgrids: Energy management by strategic deployment of DERs-A comprehensive survey. Renew. Sustain. Energy Rev. 2011, 15, 4348-4356. [CrossRef]

41. Morris, G.Y.; Abbey, C.; Joos, G.; Marnay, C. A Framework for the Evaluation of the Cost and Benefits of Microgrids. In CIGRE Int. Symposium; 2011; pp. 1-14. Available online: https://www.osti.gov/servlets/purl/ 1050451/ (accessed on 15 September 2011).

42. Newman, B.Y.D. Right-sizing the grid. Mech. Eng. 2015, 137, 34-39. [CrossRef]

43. Rebours, Y.G.; Kirschen, D.S.; Trotignon, M. A Survey of Frequency and Voltage Control Ancillary Services-Part I: Technical Features. IEEE Trans. Power System. 2007, 22, 350-357. [CrossRef]

44. Rebours, Y.; Kirschen, D.S.; Trotingnon, M.; Rossignol, S. A Comprehensive Assessment of Markets for Frequency and Voltage control Ancillary Services. Ph.D. Thesis, CCSD, Las Vegas, NV, USA, 2008. Available online: https://tel.archives-ouvertes.fr/tel-00370805 (accessed on 25 March 2009).

45. Blanco, H.; Faaij, A. A review at the role of storage in energy systems with a focus on Power to Gas and long-term storage. Renew. Sustain. Energy Rev. 2018, 81, 1049-1086. [CrossRef]

46. Kirschen, D.; Strbac, G. Fundamentals of Power System Economics. John Wiley \& Sons; 2004. Available online: http://www.cppa.gov.pk/DownloadFiles/Market\%20Literature/Fundamentals\%20of\%20Power\% 20System\%20Economics.pdf-181002094648397.pdf (accessed on 15 December 2020).

47. Švigir, N.; Kuzle, I.; Bosnjak, D. Ancillary Services in Deregulated Power Systems, WSEAS International conference on power systems. In Proceedings of the 8th WSEAS International Conference on POWER SYSTEMS (PS 2008), Santander, Cantabria, Spain, 23-25 September 2008.

48. Explanatory Memorandum: Introduction of Ancillary Services in India. 2015. Available online: http: //www.cercind.gov.in/2015/draft_reg/Ancillary_Services.pdf (accessed on 15 December 2020).

49. Hirst, E.; Kirby, B. Allocating Costs of Ancillary Services: Contingency Reserves and Regulation. 2016. ORNL/TM 2003, 152. Available online: http://www.consultkirby.com/files/Tm2003-152_Allocate_Res_Reg Cost.pdf (accessed on 15 December 2020).

50. Federal Register, United States of America. 2019; p. 20426. Available online: https://www.federalregister.gov/ citation/81-FR-20426 (accessed on 4 July 2016).

51. Guide to Ancillary Services in the National. 2015. Available online: https://www.aemo.com.au/-/media/Files/ PDF/Guide-to-Ancillary-Services-in-the-National-Electricity-Market.pdf (accessed on 15 December 2020).

52. Methods and Tools for Costing Ancillary Services, CIGRE Task Force. Electra. 2001. Available online: https://e-cigre.org/publication/ELT_196_7 (accessed on 15 December 2020).

53. Günter, N.; Marinopoulos, A. Energy storage for grid services and applications: Classification, market review, metrics, and methodology for evaluation of deployment cases. J. Energy Storage 2016, 8, 226-234. [CrossRef]

54. Load-Frequency Control and Perfromance, UCTE Operation Handbook. 2009, pp. 1-32. Available online: https://eepublicdownloads.blob.core.windows.net/public-cdn-container/clean-documents/pre2015/ publications/ce/oh/appendix1_v19.pdf (accessed on 16 June 2004). 
55. Shi, Q.; Li, F.; Hu, Q.; Wang, Z. Dynamic demand control for system frequency regulation: Concept review, algorithm comparison, and future vision. Electr. Power Syst. Res. 2018, 154, 75-87. [CrossRef]

56. Hernández, J.C.; Sanchez-sutil, F.; Vidal, P.G.; Rus-casas, C. Primary frequency control and dynamic grid support for vehicle-to-grid in transmission systems. Electr. Power Energy Syst. 2018, 100, 152-166. [CrossRef]

57. Hydroelectric Power, U.S. Department of Interior, Power Resources Office. 2005; pp. 1-26. Available online: https://www.usbr.gov/power/edu/pamphlet.pdf (accessed on 15 December 2020).

58. Izadkhast, S.; Garcia-gonzalez, P.; Frías, P. An Aggregate Model of Plug-In Electric Vehicles for Primary Frequency Control. IEEE Trans. Power Syst. 2020, 30, 1475-1482. [CrossRef]

59. Erik, E.; Michael, M.; Brendan, K. A Comprehensive Review of Current Strategies, Studies, and Fundamental Research on the Impact that Increased Penetration of Variable Renewable Generation has on Power System Operating Reserves. National Laboratory of the U.S. Department of Energy, Office of Energy Efficiency \& Renewable Energy; 2011. Available online: https://www.nrel.gov/docs/fy11osti/51978.pdf (accessed on 15 December 2020).

60. Thien, T.; Schweer, D.; Moser, A.; Uwe, D. Real-world operating strategy and sensitivity analysis of frequency containment reserve provision with battery energy storage systems in the german market. J. Energy Storage 2017, 13, 143-163. [CrossRef]

61. Kumar, G.V.B.; Sarojini, R.K.; Palanisamy, K.; Padamnabhan, S.K.; Holm-nielsen, J.B. Large Scale Renewable Energy Integration: Issues and Solutions. Energies 2019, 12, 1996. [CrossRef]

62. Wang, X.; Wang, C.; Xu, T.; Guo, L.; Li, P.Y.; Meng, H. Optimal voltage regulation for distribution networks with multi-microgrids. Appl. Energy. 2018, 210, 1027-1036. [CrossRef]

63. B. Operations, PJM Manual. 2019, p. 12. Available online: https://pjm.com/-/media/documents/manuals/ m12-redline.ashx (accessed on 26 March 2020).

64. Mahzarnia, M.M.; Sheikholislami, A.; Adabi, J. A voltage stabilizer for a microgrid system with two types of distributed generation resources. IIUM Eng. J. 2013, 14, 191-205. [CrossRef]

65. Bevrani, H.; Ghosh, A.; Ledwich, G.F. Renewable energy sources and frequency regulation: Survey and new perspectives. IET Renew. Power Gen. 2010. [CrossRef]

66. Dehghanpour, K.; Afsharnia, S. Electrical demand side contribution to frequency control in power systems: A review on technical aspects. Renew. Sustain. Energy Rev. 2015, 41, 1267-1276. [CrossRef]

67. Ulbig, A.; Borsche, T.S.; Andersson, G. Impact of Low Rotational Inertia on Power System Stability and Operation. IFAC Proc. Vol. 2014, 47, 7290-7297. [CrossRef]

68. Díaz-gonzález, F.; Hau, M.; Sumper, A.; Gomis-bellmunt, O. Participation of wind power plants in system frequency control: Review of grid code requirements and control methods. Renew. Sustain. Energy Rev. 2014, 34, 551-564. [CrossRef]

69. Tielens, P.; Van Hertem, D. Receding Horizon Control of Wind Power to Provide Frequency Regulation. IEEE Trans. Power Syst. 2017, 32, 2663-2672. [CrossRef]

70. Yu, M.; Booth, C.D.; Roscoe, A.J. A Review of Control Methods for providing frequency response in VSC-HVDC transmission systems. In Proceedings of the 2014 49th International Universities Power Engineering Conference (UPEC), Cluj-Napoca, Romani, 2-5 September 2014; pp. 1-6. [CrossRef]

71. Revel, G.; Leon, A.E.; Alonso, D.M.; Moiola, J.L. Dynamics and Stability Analysis of a Power System with a PMSG-Based Wind Farm Performing Ancillary Services. IEEE Trans. Circuits Syst. I Regul. Pap. 2014, 61, 2182-2193. [CrossRef]

72. Dreidy, M.; Mokhlis, H.; Mekhilef, S. Inertia response and frequency control techniques for renewable energy sources: A review. Renew. Sustain. Energy Rev. 2017, 69, 144-155. [CrossRef]

73. Kanchanaharuthai, A.; Chankong, V.; Kenneth, A. Transient Stability and Voltage Regulation in Multimachine Power Systems Vis- à -Vis STATCOM and Battery Energy Storage. IEEE Trans. Power Syst. 2015, 30, 2404-2416. [CrossRef]

74. Justo, J.J.; Mwasilu, F.; Jung, J. Enhanced crowbarless FRT strategy for DFIG based wind turbines under three-phase voltage dip. Electr. Power Syst. Res. 2017, 142, 215-226. [CrossRef]

75. Ambati, B.B.; Kanjiya, P.; Khadkikar, V. A Low Component Count Series Voltage Compensation Scheme for DFIG WTs to Enhance Fault Ride-Through Capability. IEEE Trans. Energy Convers. 2015, 30, 208-217. [CrossRef]

76. Huang, P.H.; El Moursi, M.S.; Hasen, S.A. Novel Fault Ride-Through Scheme and Control Strategy for Doubly Fed Induction Generator-Based Wind Turbine. IEEE Trans. Energy Convers. 2015, 30, 635-645. [CrossRef] 
77. Mendes, V.F.; De Sousa, C.V.; Rabelo, B.C.; Hofmann, W. Modeling and Ride-Through Control of Doubly Fed Induction Generators during Symmetrical Voltage Sags. IEEE Trans. Energy Convers. 2011, 26, 1161-1171. [CrossRef]

78. Hussein, A.A.; Ali, M.H. Comparison among series compensators for transient stability enhancement of doubly fed induction generator based variable speed wind turbines. IET. Renew. Power Gen. 2016, 10, 116-126. [CrossRef]

79. Guo, W.; Xiao, L.; Dai, S.; Xu, X.; Li, Y.; Wang, Y. Evaluation of the Performance of BTFCLs for Enhancing LVRT Capability of DFIG. IEEE Trans. Power Electron. 2015, 30, 3623-3637. [CrossRef]

80. Vidal, J.; Abad, G.; Arza, J.; Aurtenechea, S. Single-Phase DC Crowbar Topologies for Low Voltage Ride Through Fulfillment of High-Power Doubly Fed Induction Generator-Based Wind Turbines. IEEE Trans. Energy Convers. 2013, 28, 768-781. [CrossRef]

81. Huang, P.; Shawky, M.; Moursi, E.; Xiao, W.; Kirtley, L.K., Jr. Novel Fault Ride-Through Configuration and Transient Management Scheme for Doubly Fed Induction Generator. IEEE Trans. Energy Convers. 2013, 28, 86-94. [CrossRef]

82. Shen, Y.; Ke, D.P.; Sun, Y.Z.; Kirschen, D.S.; Qiao, W.; Deng, X.T. Advanced Auxiliary Control of an Energy Storage Device for Transient Voltage Support of a Doubly Fed Induction Generator. IEEE Trans. Sustain. Energy 2016, 7, 63-76. [CrossRef]

83. Yan, X.; Gu, C.; Zhang, X. Robust Optimization-Based Energy Storage Operation for System Congestion Management. IEEE Syst. J. 2019, 1-9. [CrossRef]

84. Bai, L.; Wang, J.; Wang, C.; Chen, C.; Li, F. Distribution Locational Marginal Pricing (DLMP) for Congestion Management and Voltage Support. IEEE Trans. Power Syst. 2018, 33, 4061-4073. [CrossRef]

85. Crampes, C.; Trochet, J. Economics of stationary electricity storage with various charge and discharge durations. J. Energy Storage 2019, 24, 100746. [CrossRef]

86. Brahmendra Kumar, G.V.; Kumar, G.A.; Eswararao, S.; Gehlot, D. Modelling and Control of BESS for Solar Integration for PV Ramp Rate Contro. In Proceedings of the 2018 International Conference on Computation of Power, Energy, Information and Communication (ICCPEIC), Chennai, India, 28-29 March 2018; pp. 368-374.

87. Kalyani, M.K.; Vaidya, G.A. Ancillary Services through Microgrid for Grid Stabilty and Relaibility. 2017. Available online: https:/www.electricalindia.in/ancillary-services-through-microgrid-forgrid-security-reliability/\#: \{\}:text=T\%26D-,Ancillary\%20services\%20through\%20Microgrid\%20for\% 20Grid\%20Security \%20\%26\%20Reliability,of\%20system\%20and\%20reduce\%20congestion (accessed on 5 September 2017).

88. Zhang, S.; Tang, Y. Optimal schedule of grid-connected residential PV generation systems with battery storages under time-of-use and step tariffs. J. Energy Storage 2019, 23, 175-182. [CrossRef]

89. Bassett, K.; Carriveau, R.; Ting, D.S. Energy arbitrage and market opportunities for energy storage facilities in Ontario. J. Energy Storage 2018, 20, 478-484. [CrossRef]

90. Luo, X.; Wang, J.; Dooner, M.; Clarke, J. Overview of current development in electrical energy storage technologies and the application potential in power system operation. Appl. Energy 2014, 137, 511-536. [CrossRef]

91. Lavoine, O.; Regairaz, F.; Baker, T.; Belmans, R.; Meeus, L.; Vandezande, L.; Hewicker, C.; Matsubara, Y.; Pereira, R.; Torres, E.; et al. Ancillary Services: An Overview of International Practices. Electra 2010, 252, 86-91. Available online: http://hdl.handle.net/1814/40007. (accessed on 15 December 2020).

92. Kim, A.; Seo, H..; Kim, G.; Park, M.; Yu, I.; Otsuki, Y.; Tamura, J.; Kim, S.; Sim, K.; Seong, K. Operating Characteristic Analysis of HTS SMES for Frequency Stabilization of Dispersed Power Generation System. IEEE Trans. Appl. Super Conduct. 2010, 20, 1334-1338.

93. Tan, X.; Li, Q.; Wang, H. Advances and trends of energy storage technology in Microgrid. Int. J. Electr. Power Energy Syst. 2013, 44, 179-191. [CrossRef]

94. Ancillary Services Unbundling Electricity Products-An Emerging Market Eurelectric. 2004. Available online: http://pierrepinson.com/31761/Literature/Eurelectric2004-ancillaryservices.pdf (accessed on 15 December 2020).

95. FERC-Federal Energy Regulatory Commission. Promoting Wholesale Competition through Open-Access Non-Discriminatory Transmission Service by Public Utilities. 2005. Available online: https://www.ferc.gov/ whats-new/comm-meet/091505/E-1.pdf (accessed on 24 May 1996). 
96. Summary of Discussion Paper on Re-designing Ancillary Services Mechanism in India. 2018; pp. 1-51. Available online: cercind.gov.in/2018/draft_reg/DP.pdf (accessed on 15 December 2020).

97. Ming, Z.; Ximei, L.; Lilin, P. The ancillary services in China: An overview and key issues. Renew. Sustain. Energy Rev. 2014, 36, 83-90. [CrossRef]

98. Module 6: Ancillary Services, National Programme on Technology Enhanced Learning. Available online: http://150.107.117.36/NPTEL_DISK4/NPTEL_Contents/Web_courses/Phase2_web/ 108101005/ancillary\%20service\%20management/introduction.html. (accessed on 15 December 2020).

99. Palizban, O.; Kauhaniemi, K.; Guerrero, J.M. Microgrids in active network management-Part I: Hierarchical control, energy storage, virtual power plants, and market participation. Renew. Sustain. Energy Rev. 2014, 36, 428-439. [CrossRef]

100. Report, Ancillary Services. 2018, pp. 1-48. Available online: https://www.dena.de/fileadmin/dena/ Publikationen/PDFs/2019/2018_Innovation_report_ancillary_services.pdf. (accessed on 15 December 2020).

101. Singh, G.; Dey, K.; Kumar, K.V.N.P.; Kumar, A.; Rehman, S.; Gaur, K. Ancillary Services in India-Evolution, Implementation and Benefits. In Proceedings of the 2016 National Power Systems Conference (NPSC), Bhubaneswar, India, 19-21 December 2016; pp. 1-6. [CrossRef]

102. Supercharged: Challenges and Opportunities in Global Battery Storage Markets. 2019, pp. 1-26. Available online: https://www2.deloitte.com/content/dam/Deloitte/bg/Documents/energy-resources/gx-er-challengesopportunities-global-battery-storage-markets.pdf. (accessed on 15 December 2020).

103. Annual Electricity Report in France. 2015. Available online: https://www.agora-energiewende.de/fileadmin2/ Projekte/2014/CP-Frankreich/CP_France_1015_update_web.pdf (accessed on 15 December 2020).

104. ABC and AGC Interface Requirements AEMO. 2018. Available online: https://www.aemo.com.au/-/media/ files/electricity/wem/security_and_reliability/ancillary-services/2018/abc-and-agc-requirements-sept-2018. pdf?la=en\&hash=DF420D332F1552755E73C8A258D962F0 (accessed on 15 December 2020).

105. Energy, U.K. Ancillary Services Report. 2017. Available online: https://www.energy-uk.org.uk/publication. html?task=file.download\&id=6138 (accessed on 15 December 2020).

106. Vietor, R.H.K.; Thomson, H.S. Mexico's Energy Reform. 2017, pp. 1-32. Available online: https://www.hbs. edu/faculty/Pages/item.aspx?num=52187 (accessed on 23 January 2017).

107. Asgari, M.H.; Tabatabaei, M.J.; Riahi, R.; Mazhabjafari, A.; Mirzaee, M.; Bagheri, H.R. Establishment of regulation service market in iran restructured power system. Can. Conf. Electr. Comput. Eng. 2008, 713-718. [CrossRef]

108. Energy Services Market Intelligence Report. 2018. Available online: https://www.greencape.co.za/assets/ Uploads/GreenCape-Energy-Services-2018-MIR-25052019.pdf. (accessed on 15 December 2020).

109. Electricity Market Side Service Regulation Market, Turkey: Purpose, Scope, Basis and Definitions. 2017. Available online: https:/www.lexology.com/library/detail.aspx?g=2577d4f0-9783-4346-951c-9f8ac552ffbb (accessed on 26 November 2017).

110. Mengelkamp, E.; Gärttner, J.; Rock, K.; Kessler, S.; Orsini, L. Designing microgrid energy markets A case study: The Brooklyn Microgrid. Appl. Energy 2018, 210, 870-880. [CrossRef]

111. Kumar, G.V.B.; Palanisamy, K. Interleaved Boost Converter for Renewable Energy Application with Energy Storage System. In Proceedings of the 2019 IEEE 1st International Conference on Energy, Systems and Information Processing (ICESIP), Chennai, India, 4-6 July 2019; pp. 1-5. [CrossRef]

112. Lo, C.; Hobbs, B.F. A cooperative game theoretic analysis of incentives for microgrids in regulated electricity markets. Appl. Energy 2016, 169, 524-541. [CrossRef]

113. Yue, J.; Hu, Z.; Anvari-moghaddam, A. A Multi-Market-Driven Approach to Energy Scheduling of Smart Microgrids in Distribution Networks. Sustainability 2019, 11, 301. [CrossRef]

114. Zhang, C.; Wu, J.; Zhou, Y.; Cheng, M.; Long, C. Peer-to-Peer energy trading in a Microgrid. Appl. Energy 2018, 220, 1-12. [CrossRef]

115. Soshinskaya, M.; Crijns-graus, W.H.J.; Guerrero, J.M.; Vasquez, J.C. Microgrids: Experiences, barriers and success factors. Renew. Sustain. Energy Rev. 2014, 40, 659-672. [CrossRef]

116. Meyer, D.; Glotfelty, J.W. U.S.-Canada Power System Outage Task Force, Energy Department. 2003. Available online: https://digital.library.unt.edu/ark:/67531/metadc26005/ (accessed on 14 August 2003). 
117. Wang, W.; Lu, Z. Cyber security in the Smart Grid: Survey and challenges. Comput. Netw. 2018, 57, $1344-1371$. [CrossRef]

118. Committee on the Societal and Economic Impacts of Severe Space Weather Events: A Workshop, National Research Council United States of America. 2008. Available online: http://lasp.colorado.edu/home/ wpcontent/uploads/2011/07/lowres-Severe-Space-Weather-FINAL.pdf. (accessed on 15 December 2020).

119. Maize, K. The Great Solar Storm of 2012? Power Mag. 2011. Available online: http://www.powermag.com/ the-great-solar-storm-of-2012 (accessed on 11 February 2011).

120. Foster, J.S.; Gjelde, E.; Graham, W.R.; Hermann, R.J.; Kluepfel, H.M.; Lawson, R.L.; Gordon, K.S.; Lowell, L.W., Jr.; Joan, B.W. Report of the Commission to Assess the Threat to the United States from Electromagnetic Pulse (EMP) Attack. Volume 1: Executive Report. DTIC Document. 2004. Available online: http://www.empcommission.org/docs/empc_exec_rpt.pdf (accessed on 15 December 2020).

121. Maize, K. EMP: The Biggest Unaddressed Threat to the Grid. Power Mag. 2013. Available online: http://www.powermag.com/emp-the-biggest-unaddressed-threat-to-the-grid (accessed on 1 July 2013).

122. Mikova, B.T. Cyber Attack on Ukrainian Power Grid. 2018. Available online: https://is.muni.cz/th/uok5b/ BP_Mikova_final.pdf. (accessed on 15 December 2020).

123. Times of Israel. Steinitz: Israel's Electric Authority Hit by Severe Cyber-Attack. 2016. Available online: https://www.timesofisrael.com/steinitz-israels-electric-authority-hit-by-severe-cyber-attack/ (accessed on 26 January 2016).

124. Smith, R. Assault on California Power Station Raises Alarm on Potential for Terrorism. Wall Street Journal. 2014. Available online: https://www.wsj.com/articles/assault-on-california-power-station-raises-alarm-onpotential-for-terrorism-1391570879 (accessed on 5 February 2014).

125. Smith, R. How America Could Go Dark. Wall Street Journal. 2016. Available online: https://www.wsj.com/ articles/how-america-could-go-dark-1468423254 (accessed on 14 July 2016).

126. Campbell, R.J. Weather-Related Power Outages and Electric System Resiliency, Congressional Research Service, Library of Congress. 2012. Available online: https://fas.org/sgp/crs/misc/R42696.pdf (accessed on 28 August 2012).

127. Tweed, K. Con Ed to Batteries, Microgrids and Efficiency to Delay \$1B Substation Build. 2014. Available online: https://www.greentechmedia.com/articles/read/con-ed-looks-to-batteries-microgrids-and-efficiencyto-delay-1b-substation (accessed on 17 July 2014).

128. Lovins, A.B. Rocky Mountain Institute editors. In Small Is Profitable, 1st ed.; Rocky Mountain Institute: Snowmass, CO, USA, 2002; Available online: https://rmi.org/wp-content/uploads/2017/05/RMI_Document_ Repository_Public-Reprts_U02-09_SmallIsProfitableBook.pdf. (accessed on 15 December 2020).

129. Asmus, P.; Larence, M. Emerging Microgrid Business Models. 2016. Available online: http://www.g20ys.org/ upload/auto/abf2f0a71ea657d34c551214a4ff7045515582eb.pdf. (accessed on 15 December 2020).

130. Guerrero, J.M.; Loh, P.C.; Lee, T.; Chandorkar, M. Advanced Control Architectures for Intelligent Microgrids-Part II: Power Quality, Energy Storage, and AC/DC Microgrids. IEEE Trans. Ind. Electron. 2013, 60, 1263-1270. [CrossRef]

131. Katiraei, F.; Iravani, R.; Hatziargyriou, N.; Dimeas, A. Microgrids Management-Control and Operation Aspects of Microgrids. IEEE Power Energy Mag. 2008, 6, 54-65. [CrossRef]

132. Lopes, J.A.P.; Madureira, A.G.; Moreiran, C.C.L.M. A view of microgrids. Wiley Interdiscip. Rev. Energy Environ. 2013, 2, 86-103. [CrossRef]

133. Bhatnagar, D.; Currier, A.; Hernandez, J.; Ma, O.; Kirby, B. Market and Policy Barriers to Energy Storage Deployment. Sandia National Laboratories/Office of Energy Efficiency and Renewable Energy; 2013. Available online: https://www.sandia.gov/ess-ssl/publications/SAND2013-7606.pdf (accessed on 15 December 2020).

134. Byrne, R.H.; Concepcion, R.J.; Silva-monroy, A. Estimating Potential Revenue from Electrical Energy Storage in PJM. 2016; pp. 1-5. Available online: https://www.osti.gov/servlets/purl/1239334 (accessed on 1 February 2016).

135. Denholm, P.; O'Connell, M.; Brinkman, G.; Jorgenson, J. Overgeneration from Solar Energy in California: A Field Guide to the Duck Chart, Natl. Renew Energy Lab Tech rep. NRELTP-6A20-65023; 2015. Available online: https://www.nrel.gov/docs/fy16osti/65023.pdf (accessed on 15 December 2020). 
136. California Independent System Operator. What the Duck Curve Tells Us about Managing a Green Grid. 2016. Available online: https://www.caiso.com/Documents/FlexibleResourcesHelpRenewables_FastFacts.pdf (accessed on 15 December 2020).

137. Bebic, J. Power System Planning: Emerging Practices Suitable for Evaluating the Impact of High-Penetration Photovoltaics; National Renewable Energy Laboratory: Golden, CO, USA, 2008. Available online: https: //www.nrel.gov/docs/fy08osti/42297.pdf (accessed on 15 December 2020).

138. Hoke, A.; Butler, R.; Hambrick, J.; Kroposki, B. Maximum Photovoltaic Penetration Levels on Typical Distribution Feeders; Natl. Renew Energy Lab.: Golden, CO, USA, 2012. Available online: https://www.nrel.gov/docs/ fy120sti/55094.pdf (accessed on 15 December 2020).

139. Martin, R. Texas and California Have a Bizarre Problem: Too much Renewable Energy. MIT Technol Rev. 2016. Available online: https://www.technologyreview.com/2016/04/07/161139/texas-and-california-havetoo-much-renewable-energy/ (accessed on 7 April 2016).

140. Martin, R. Loading up on Wind and Solar Is Causing New Problems for Germany, MIT Technol Rev. 2016. Available online: https://www.technologyreview.com/2016/05/24/159991/germany-runs-up-againstthe-limits-of-renewables/ (accessed on 24 May 2016).

141. Perez, E. Investigators Find Proof of Cyber-Attack on Ukraine Power Grid. CNN. 2016. Available online: https://edition.cnn.com/2016/02/03/politics/cyberattack-ukraine-power-grid/index.html\#: \{\}:text= Washington\%20 (accessed on 4 February 2016).

142. Akhil, A.A.; Huff, G.; Aileen, B.; Currier, B.; Benzamin, C.K.; Rastler, D.M.; Chen, S.B.; Cotter, A.L.; Bradshaw, D.T.; Gauntlett, W.D.; et al. DOE/EPRI 2013 Electricity Storage Handbook in Collaboration with NRECA; Albuquerque, N.M., Ed.; Sandia National Laboratories: Albuquerque, NM, USA, 2013. Available online: https: //prod-ng.sandia.gov/techlib-noauth/access-control.cgi/2015/151002.pdf (accessed on 15 December 2020).

143. Eyer, J.; Corey, G. Energy Storage for the Electricity Grid: Benefits and Market Potential Assessment Guide, Sandia National Laboratories Report; SAND2010-0815; Sandia National Laboratories: Albuquerque, NM, USA, 2010. [CrossRef]

144. Kumar, G.V.B.; Kaliannan, P.; Padmanaban, S.; Holm-Nielsen, J.B.; Blaabjerg, F. Effective Management System for Solar PV Using Real-Time Data with Hybrid Energy Storage System. Appl. Sci. 2020, 10, 1108. [CrossRef]

145. Laaksonen, H.; Kauhaniemi, K. Control Principles for Black Start and Island Operation of Microgrid. Nordic Workshop on Power and Industrial Electronics (NORPIE/). 2008. Available online: https://aaltodoc.aalto.fi/ handle/123456789/810. (accessed on 15 December 2020).

146. Lopes, J.A.P.; Moreira, C.L.; Resende, F.O. Microgrids Black Start and Islanded Operation. 2005, pp. 22-26. Available online: http://www.montefiore.ulg.ac.be/services/stochastic/pscc05/papers/fp69.pdf (accessed on 26 August 2005).

147. Xu, G.; Xu, L.; Morrow, J. Power oscillation damping using wind turbines with energy storage systems. IET Renew. Power Gener. 2013, 7, 449-457. [CrossRef]

148. Beza, M.; Bongiorno, M. Power Oscillation Damping Controller by Static Synchronous Compensator with Energy Storage. In Proceedings of the IEEE Energy Conversion Congress and Exposition, Phoenix, AZ, USA, 17-22 September 2011; pp. 2977-2984.

149. Altin, M.; Teodorescu, R.; Jensen, B.B.; Annakkage, U.D.; Iov, F.; Kjaer, P.C. Methodology for Assessment of Inertial Response from Wind Power Plants. In Proceedings of the 2012 IEEE Power and Energy Society General Meeting, San Diego, CA, USA, 22-26 July 2012; pp. 1-8.

150. Teodorescu, R.; Rodriguez, P. Lifetime Investigations of a Lithium Iron Phosphate (lip) Battery System Connected to a Wind Turbine for Forecast Improvement and Output Power Gradient Reduction. Battcon Arch. Pap. 2012, 1-8.

151. Chua, K.H.; Lim, Y.S.; Wong, J.; Taylor, P.; Morris, E.; Morris, S. Voltage Unbalance Mitigation in Low Voltage Distribution Networks with Photovoltaic Systems. J. Electron. Sci. Technol. 2012, 10, 1-6. [CrossRef]

152. Levron, Y.; Shmilovitz, D. Power systems optimal peak-shaving applying secondary storage. Electr. Power Syst. Res. 2012, 89, 80-84. [CrossRef]

153. Callaway, D.S. Tapping the energy storage potential in electric loads to deliver load following and regulation with application to wind energy. Energy Convers. Manag. 2009, 50, 1389-1400. [CrossRef]

154. Thounthong, P.; Rael, S.; Davat, B. Analysis of Supercapacitor as Second Source Based on Fuel Cell Power Generation. IEEE Trans. Energy Convers. 2009, 24, 247-255. [CrossRef] 
155. Kim, J.; Jeon, J.; Kim, S.; Cho, C.; Park, J.H.; Kim, H.; Nam, K. Cooperative Control Strategy of Energy Storage System and Microsources for Stabilizing the Microgrid during Islanded Operation. IEEE Trans. Power Electronics. 2010, 25, 3037-3048.

156. Mercier, P.; Cherkaoui, R.; Oudalov, A. Optimizing a Battery Energy Storage System for Frequency Control Application in an Isolated Power System. IEEE Trans. Power Syst. 2009, 24, 1469-1477. [CrossRef]

Publisher's Note: MDPI stays neutral with regard to jurisdictional claims in published maps and institutional affiliations.

(C) 2020 by the authors. Licensee MDPI, Basel, Switzerland. This article is an open access article distributed under the terms and conditions of the Creative Commons Attribution (CC BY) license (http://creativecommons.org/licenses/by/4.0/). 